US Army Corps

of Engineers $s_{\circledast}$

Engineer Research and

Development Center

Installation Technology Transfer Program

\title{
Using Frozen Barriers for Containment of Contaminants
}

Anna M. Wagner and Edward Yarmak, Jr.

September 2017

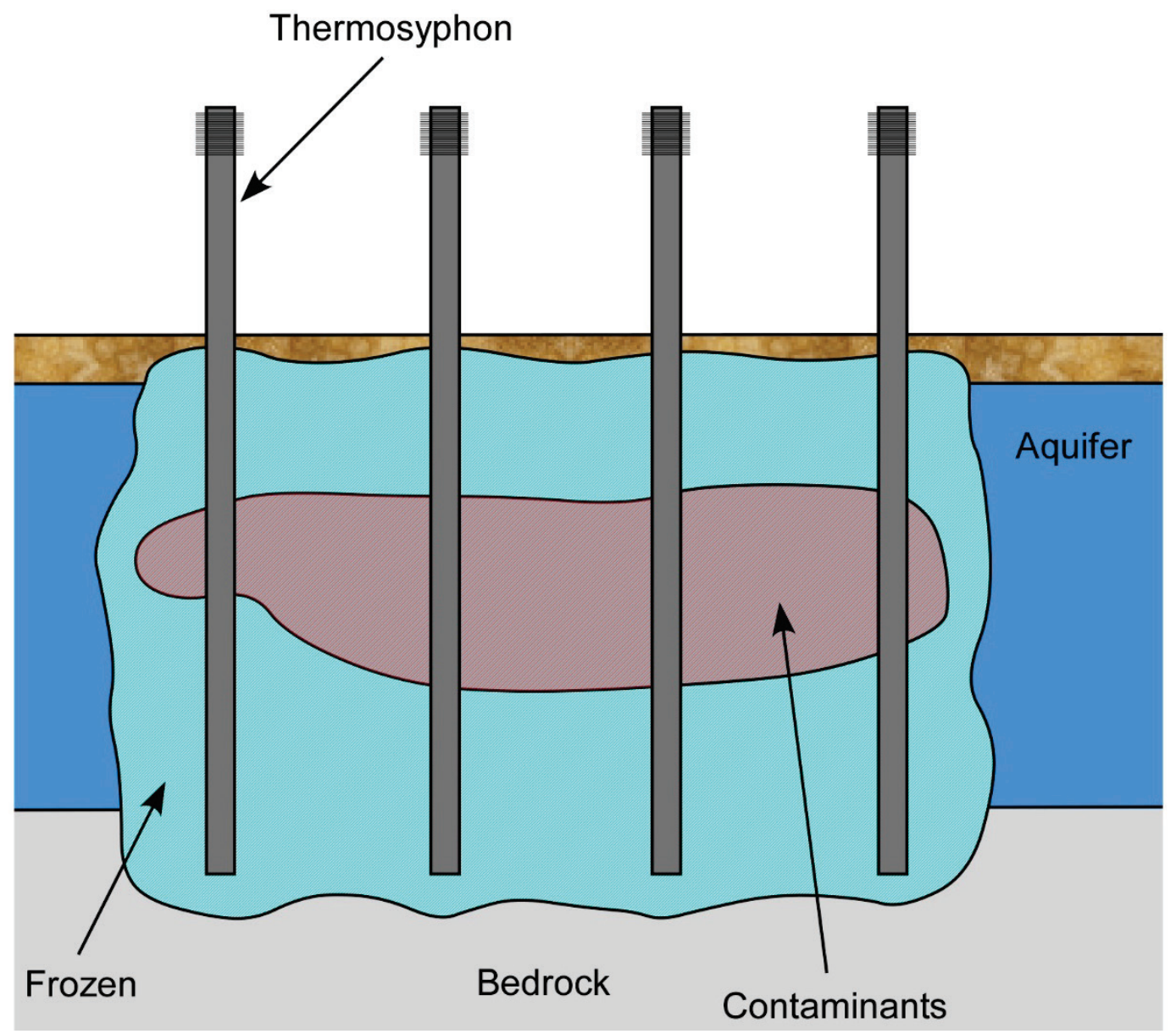

Approved for public release; distribution is unlimited. 
The U.S. Army Engineer Research and Development Center (ERDC) solves the nation's toughest engineering and environmental challenges. ERDC develops innovative solutions in civil and military engineering, geospatial sciences, water resources, and environmental sciences for the Army, the Department of Defense, civilian agencies, and our nation's public good. Find out more at www.erdc.usace.army.mil.

To search for other technical reports published by ERDC, visit the ERDC online library at http://acwc.sdp.sirsi.net/client/default. 


\section{Using Frozen Barriers for Containment of Contaminants}

Anna M. Wagner

Cold Regions Research and Engineering Laboratory

U.S. Army Engineer Research and Development Center

72 Lyme Road

Hanover, NH 03755

Edward Yarmak, Jr.

Arctic Foundations Inc.

5621 Arctic Boulevard

Anchorage, AK 99518-1667

Final report

Approved for public release; distribution is unlimited.

\footnotetext{
Prepared for Office of the Assistant Chief of Staff for Installation Management 600 Army Pentagon

Washington, DC 20310

Under Project FY12-55, "Frozen Soils as Barriers to Isolate Contaminants"
} 


\section{Abstract}

In the summer of 2011, a full-scale test of a frozen soil barrier was deployed at the Cold Regions Research and Engineering Laboratory site in Fairbanks, AK. Hybrid thermosyphons, a more efficient cooling technology than conventional ground freezing, were used to create the frozen soil. The hybrid units were actively cooled by a 4.5 kilowatt refrigeration condensing unit for 62 days. A vertical frozen barrier of 9 meters $(\mathrm{m})$ extending from a depth of $7 \mathrm{~m}$ below the surface to the ground surface was completed in 42 days, and the barrier was $1 \mathrm{~m}$ thick in 48 days. This frozen barrier installation has successfully shown that this technology can freeze the ground quickly. At the end of winter 2012, the barrier was approximately $3.8 \mathrm{~m}$ thick. This barrier thickness was maintained throughout the summer of 2012. The results showed only the top $0.5 \mathrm{~m}$ thawed even though the system was inactive for approximately a year. A cost analysis was performed to compare the cost of frozen barriers and slurry walls. It was concluded that construction and operating and maintenance costs of frozen barriers are on par with other barrier systems.

DISCLAIMER: The contents of this report are not to be used for advertising, publication, or promotional purposes. Citation of trade names does not constitute an official endorsement or approval of the use of such commercial products. All product names and trademarks cited are the property of their respective owners. The findings of this report are not to be construed as an official Department of the Army position unless so designated by other authorized documents. 


\section{Contents}

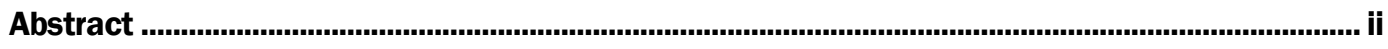

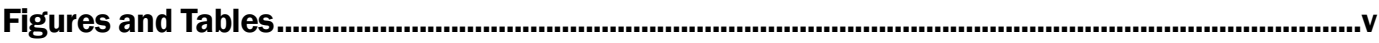

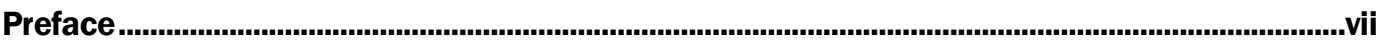

Unit Conversion Factors ................................................................................................................... viii

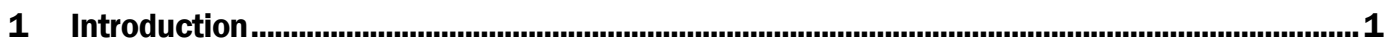

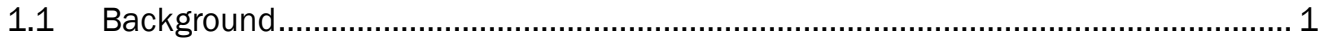

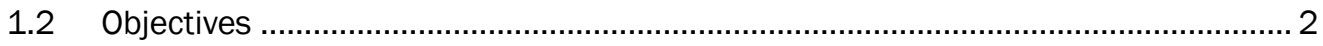

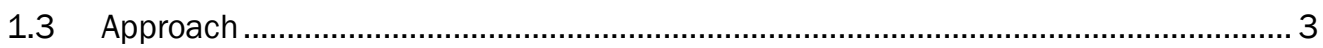

2 Vertically Engineered Barriers.................................................................................................. 4

2.1 Types of vertical barriers ............................................................................... 4

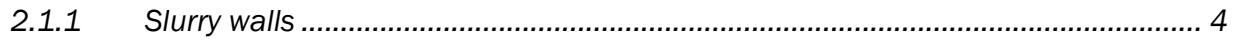

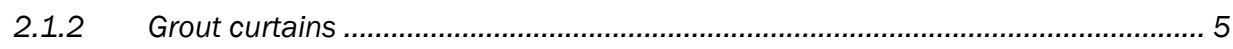

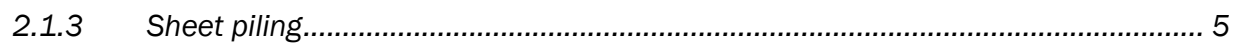

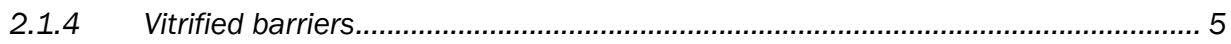

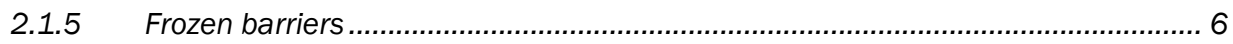

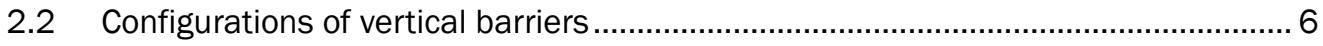

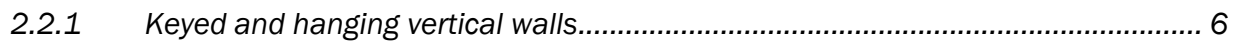

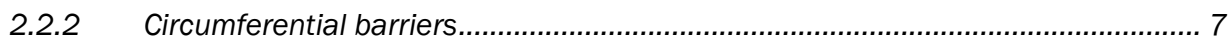

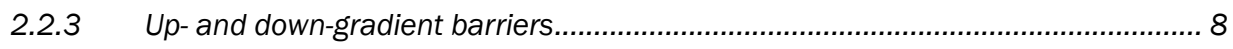

2.3 Integrity of vertical barriers .......................................................................... 10

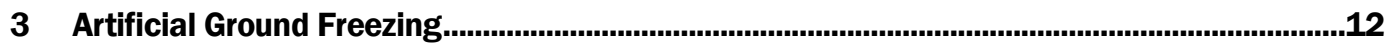

3.1 Conventional freezing techniques ................................................................. 12

3.2 Thermosyphons ......................................................................................... 13

3.3 Design of a frozen barrier ............................................................................. 15

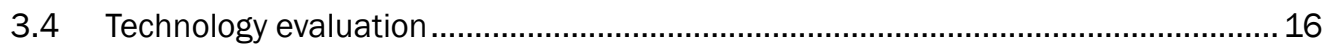

3.4.1 Advantages with frozen barriers .................................................................... 16

3.4.2 Disadvantages with frozen barriers ............................................................... 17

3.4.3 Strengths and weaknesses of containment/remediation technologies................ 18

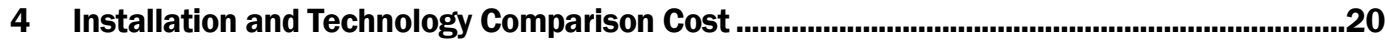

4.1 Frozen barrier cost.................................................................................................. 20

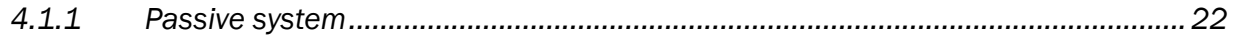

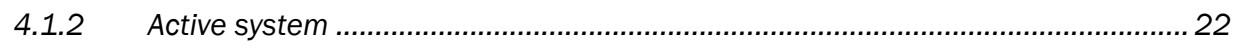

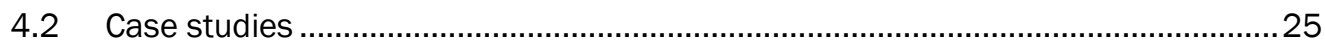

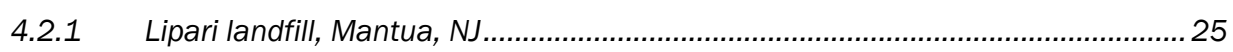

4.2.2 Sylvester/Gilson Road Superfund site, NH...................................................... 25

4.2.3 The West Valley Demonstration Project Act, West Valley, NY................................26

4.2.4 The NW Natural "Gasco" site, Portland, OR......................................................... 26

4.2.5 Cost comparison of case studies ......................................................................... 27 


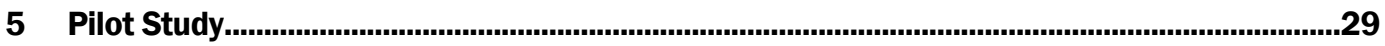

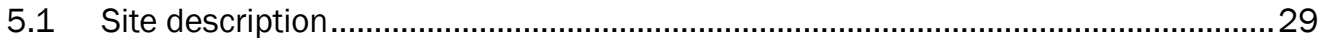

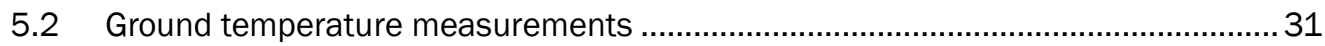

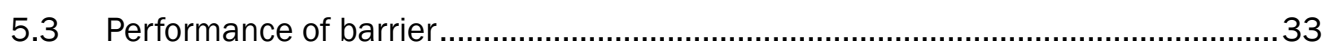

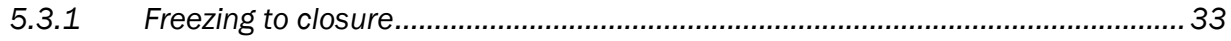

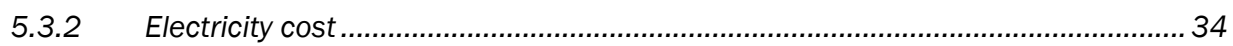

5.3.3 Passive system ............................................................................................... 34

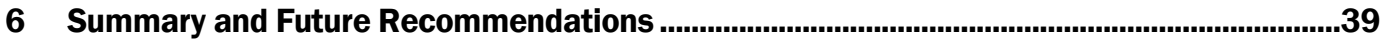

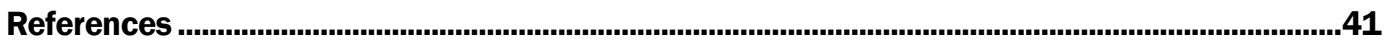

Report Documentation Page 


\section{Figures and Tables}

\section{Figures}

Figure 1. a) Keyed and b) hanging vertical wall (after Rumer and Ryan [1995]).............................. 7

Figure 2. Circumferential vertical barrier (after Rumer and Ryan [1995])........................................ 8

Figure 3. Up-gradient vertical barrier (after Rumer and Ryan [1995])..............................................

Figure 4. Down-gradient vertical barrier (after Rumer and Ryan [1995]) .........................................10

Figure 5. Thermosyphon system for hazardous waste containment at Oak Ridge National Laboratory, TN.

Figure 6. Thermoprobes at the Long Lake Outlet Dam, Ekati Diamond Mine, Northwest

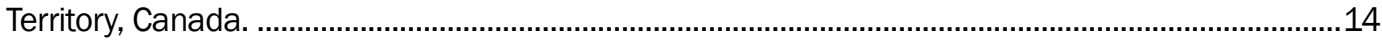

Figure 7. Illustration of a passive thermosyphon.

Figure 8. Annual average air temperatures are shown in black while winter average air temperatures (December, January, and February during the years of 1971 to 2000) are shown in red (temperature data available at http://www.ncdc.noaa.gov/).

Figure 9. Installation cost of a passive barrier with the black line representing the average cost and the gray field is the $15 \%$ varied cost from the average cost.

Figure 10. Installation cost of an active barrier with the black line representing the average cost and the gray field is the $\pm 15 \%$ range from the average cost.

Figure 11. Average electricity cost in the United States for May 2012 (USEIA 2012).......................24

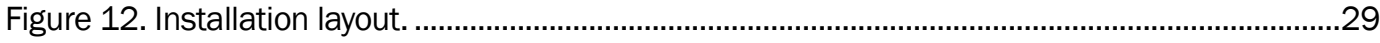

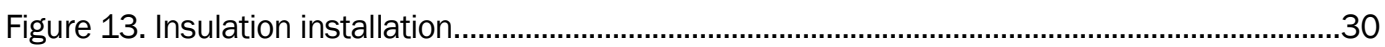

Figure 14. Complete installation of the hybrid thermosyphons and refrigeration unit.......................31

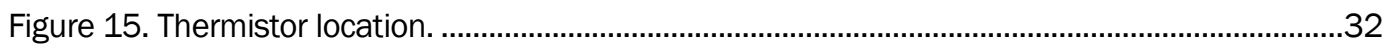

Figure 16. Layout of ground temperature monitoring locations. ..........................................................33

Figure 17. Electricity usage and average air temperatures during the active phase.........................34

Figure 18. Ground temperatures for several locations (ITTP1, ITTP7, ITTP10, ITTP11, and ITTP50) at various ground depths: surface (top, interface between ground surface, and insulation), $0.6 \mathrm{~m}, 1.2 \mathrm{~m}$, and $1.8 \mathrm{~m}$. The black dotted line indicates the $0^{\circ} \mathrm{C}$ freezing.

Figure 19. Ground temperatures for several locations (ITTP1, ITTP7, ITTP10, ITTP11, and ITTP50) at various ground depths: $2.4 \mathrm{~m}$ (top), $3.0 \mathrm{~m}, 4.6 \mathrm{~m}$, and $6.1 \mathrm{~m}$ (note that ITTP50 in second, third, and fourth graphs shows depths of $2.4 \mathrm{~m}, 4.0 \mathrm{~m}$, and $5.5 \mathrm{~m}$, respectively). The black dotted line indicates the $0{ }^{\circ} \mathrm{C}$ freezing.

Figure 20. Ground temperatures for several locations (ITTP1, ITTP7, ITTP10, ITTP11, and ITTP50) at various ground depths: surface, $7.6 \mathrm{~m}, 9.1 \mathrm{~m}$, and $10.7 \mathrm{~m}$ (note that ITTP50 in all graphs shows depths of $7.0 \mathrm{~m}, 8.5 \mathrm{~m}$, and $10.0 \mathrm{~m}$, respectively). The black dotted line indicates the $0^{\circ} \mathrm{C}$ freezing.

Figure 21. Ground temperatures for ITTP50 at depths of $11.6 \mathrm{~m}, 13.1 \mathrm{~m}$, and $14.6 \mathrm{~m}$. The black dotted line indicates the $0{ }^{\circ} \mathrm{C}$ freezing.

\section{Tables}

Table 1. Advantages and benefits of a hybrid thermosyphon system. 
Table 2. Strengths and weaknesses of competing technologies (from Johnson et al.

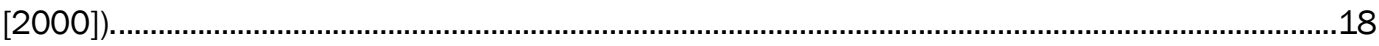

Table 3. Cost comparison between slurry wall and frozen barrier case study installations. .............28 


\section{Preface}

This study was conducted at Fort Wainwright, AK, for the U.S. Army Assistant Chief of Staff for Installation Management under Installation Technology Transfer Program, Project FY12-55, "Frozen Soils as Barriers to Isolate Contaminants."

At the time of publication, Dr. Justin Berman was Chief, Biogeochemical Sciences Branch (CEERD-RRN), U.S. Army Engineer Research and Development Center (ERDC), Cold Regions Research and Engineering Laboratory (CRREL), and CDR J. D. Horne, USN (Ret), was Chief, Research and Engineering Division, ERDC-CRREL (CEERD-RR). The Deputy Director of ERDC-CRREL was Dr. Lance D. Hansen, and the Director was Dr. Joseph L. Corriveau.

COL Bryan S. Green was the Commander of ERDC, and Dr. David W. Pittman was the Director. 


\section{Unit Conversion Factors}

\begin{tabular}{|l|r|l|}
\hline Multiply & \multicolumn{1}{|c|}{ By } & To Obtain \\
\hline degrees Fahrenheit & $(\mathrm{F}-32) / 1.8$ & degrees Celsius \\
\hline feet & 0.3048 & meters \\
\hline horsepower (550 foot-pounds force per second) & 745.6999 & watts \\
\hline inches & 0.0254 & meters \\
\hline mils & 0.0254 & millimeters \\
\hline pounds (mass) & 0.45359237 & kilograms \\
\hline
\end{tabular}




\section{Introduction}

\subsection{Background}

As of 1996, pump-and-treat systems at Department of Defense (DoD) sites alone cost $\$ 40$ million per year (DoD 1998). At 75 pump-and-treat sites, it was concluded that cleanup goals would not be feasible within a reasonable time. For future groundwater cleanup sites, it was recommended that other techniques should be explored. Due to the limitations of both pump-and-treat and other potential technologies and the high clean-up costs, explicit policies were also issued by federal and state agencies leading to more acceptance of containment of contaminants as an acceptable treatment option (NRC 2005).

Some of the major sources of groundwater contaminants are above-ground and below-ground storage tanks, septic systems, hazardous waste sites, and landfills. By isolating the source, physical containment systems can prevent or reduce the degradation of groundwater outside the contained area. A physical containment system commonly consists of a vertical engineered barrier (VEB) or cut-off wall, a low-permeability cap, and an underlying low-permeability unit or aquitard to which the barrier is keyed. Typically, containment systems also include groundwater extraction and monitoring sub-systems. The VEBs are commonly slurry walls (native soils enriched with bentonite or another type of clay) and a cap that reduces infiltration into the containment system. Other containment technologies are reactive barriers, sheet pile walls, grouted barriers, or frozen barriers. Except for the frozen barrier, these are all permanent structures that, once installed, are difficult and expensive to remove. A frozen barrier is unique in that, in most cases, a frozen barrier may be removed by simply deactivating the freezing system once containment is no longer required (Long and Yarmak 2000).

Artificial ground freezing has primarily been used for deep excavation, tunneling and underground construction (Hass and Schafers 2005). It was introduced for coal mine shafts in South Wales and patented by F.H. Poetsch in 1863. The first artificial ground freezing in the United States occurred in 1888 to a depth of 30 meters (m) at Chapin Mine Co., Michigan, and consisted of 26 pipes spaced evenly on $9 \mathrm{~m}$ circle (Donaldson 1912). One of the deeper constructions of an artificially frozen 
shaft is the $528 \mathrm{~m}$ deep Rheinberg ventilation shaft in Germany (Smoltczyk et al. 1991). Freezing at Shandong Longgu Mine in China reaches depths of $650 \mathrm{~m}$. At underground construction and tunneling projects, artificial ground freezing is used for groundwater cutoff, encapsulation of fill debris within a matrix of frozen ground, and improvements of soil strength along the excavated area. At Cameco's Uranium mines in Canada, ground freezing has been used to control radon gas release (Newman et al. 2011). More recently, there has been an interest to use artificial ground freezing for containment of contaminants.

The concept of using a frozen barrier for containment of contaminants was proposed by the Department of Energy (DOE) in 1995 (USDOE 1995) where conventional freezing techniques were used to demonstrate how to contain hazardous and radioactive contaminants in soils and groundwater. At that installation a V-shaped containment structure was installed, and the contact area of the frozen envelope was approximately $200 \mathrm{~m}^{2}$, and the volume of frozen soil was approximately $1,000 \mathrm{~m}^{3}$. Sayles and Iskandar (1995) investigated using the barrier for hazardous waste containment. Andersland et al. (1996a) studied using frozen, gravelly sand barriers for containment of liquid contaminants. They presented three areas where artificial frozen barriers can be used: (1) containment of contaminants during site remediation, (2) prevention of further spreading of contaminants, and (3) secondary containment of hazardous waste. Interim measures are often necessary to control or mitigate contaminant movement until final remediation alternatives are implemented. For example, at the Lipari Landfill in New Jersey, it took approximately 14 years after the leachate was found until a containment system was installed (Ramage 1988). This technology could be implemented while waiting for a decision on remediation technology. Frozen barriers can provide interim control without unduly modifying the chemical or physical nature of the site, which in turn might affect the effectiveness of any final remedial treatment. Deployment of a frozen barrier can also assure contamination within the soil will remain fixed, allowing additional time to develop remedial treatments.

\subsection{Objectives}

The objectives of this study were to test and evaluate a commercially available technology (hybrid thermosyphons). The thermosyphons were used to freeze the ground and create a frozen barrier that would be used to prevent contaminant migration to groundwater. This report includes 
documenting the performance of this barrier during the summer months, while actively freezing the ground, and then monitoring the frozen wall while in an inactive state, basically simulating either an electricity outage or a totally passive system. It also includes a cost analysis of using thermosyphons for containment of contaminants and case studies where this technology could have been installed.

\subsection{Approach}

The installation procedure of the system and initial performance was described in detail by Wagner and Yarmak (2012). In brief, the installation procedure consisted of identifying a suitable location, drilling six 203.2 millimeter $(\mathrm{mm})$ diameter holes to a depth of $10.67 \mathrm{~m}$, and lowering the bottom thermosyphon pipe sections into the holes. The top sections of the thermosyphons (i.e., the condensers) were then welded on by Arctic Foundations. A $203.2 \mathrm{~mm}$ layer of foam insulation was layered out in a $12 \times 12 \mathrm{~m}$ square on top of the ground surrounding the thermosyphons. The site was then covered with a waterproof membrane and sand to limit water infiltration and solar radiation. A Bohn air-cooled refrigeration condensing unit was then placed on top of the insulation and plumbed into the thermosyphons to provide the active cooling for the first couple of months. The refrigeration unit was inactivated in fall 2011, and the system has been running passively since the active system was turned off.

This report covers the performance of the thermosyphon test system since installation and provides an analysis of the thaw rate once the active freezing of the thermosyphons ceased. Also included is a cost analysis of installing this technology at different locations with varying climates throughout the United States. The system was installed in July of 2011, and the performance of active freezing and inactive thawing was monitored using temperature sensors installed throughout the site. Data provided in this report include soil temperatures from approximately 7 months (1 March through 3 October 2012) during periods of warm air temperatures, which demonstrates how well the passive performance of the thermosyphons maintains the barrier.

The report has six sections. Section 1 is the introduction, Section 2 provides a summary about vertical barriers, Section 3 describes artificial ground freezing, including the technology of thermosyphons, Section 4 summarizes the cost of installing thermosyphons and technology comparison, Section 5 reports results from the pilot study at Ft. Wainwright, and Section 6 presents a summary and future recommendations. 


\section{Vertically Engineered Barriers}

The earliest underground barriers for groundwater control in the United States date back to the 1940s (Ryan 1987). In a remediation design, vertical barrier walls can be used to limit the flow of contaminants off site and also to restrict the flow of uncontaminated groundwater onto the site. Generally, vertical barriers are constructed of grout slurry and plastic or steel sheet pilings. Circumferential barriers can be used to completely enclose a source of contamination, and open barriers (vertical walls) can be used for redirecting groundwater flow (Rumer and Ryan 1995; Mitchell and van Court 1997). Frozen barriers can also provide groundwater control during excavation of wastes or contaminated soil. At sites undergoing cleanup, vertical barriers can be used in the long term to reduce residual contaminant migrations (Rumer and Ryan 1995).

\subsection{Types of vertical barriers}

Slurry walls, grout curtains, sheet pilings, vitrified barriers, and frozen barriers can be used as cut-off walls to divert groundwater flow around a contaminated zone and to contain contaminated water within the barrier (Gerber and Fayer 1994). Subsurface conditions dictate the selection of a suitable vertical barrier for a site. For example, slurry walls are mostly used for softer soils whereas grout curtains are more commonly used in fractured rock (Rumer and Ryan 1995). Slurry walls and sheet pile walls are both established subsurface containment technologies (Pearlman 1999). Vertical barriers are well accepted and have been used for isolating hazardous waste and preventing the migration of pollutants since late 1970 and early 1980 os (USEPA 1998c). The original design was to use the barrier to contain the contaminants for a limited time only. As an improvement by the late 1980 s, extraction or pumping systems were installed in conjunction with vertical barriers to also allow maintenance of an inward flow through the wall at a very low rate.

\subsubsection{Slurry walls}

A soil-bentonite slurry trench cutoff wall (slurry wall) is excavated and backfilled with grout, cement, or soil-bentonite mixtures. Walls are typically $1 \mathrm{~m}$ thick and are most commonly installed vertically (Gerber and Fayer 1994). Most of the 36 sites investigated by USEPA (1998c) were designed with a $1 \mathrm{~m}$ thick wall that actually ranged in thickness between 
$0.3 \mathrm{~m}$ to $3 \mathrm{~m}$. Some of the advantages with soil-based slurry walls are that they can be installed to a depth of up to $60 \mathrm{~m}$, they can be installed relatively quickly, and they can also be used with other remediation technologies (Pearlman 1999). Disadvantages with this technique are that it is difficult to ensure proper emplacement, installation requires a mixing area, and there is a substantial amount of excavation and the need to dispose of spoil. The advantages of cement-based slurry walls are that no backfill is needed and construction can occur at limited access areas (Pearlman 1999). Cement-based slurry walls are stronger than the soilbased vertical walls; however, a low permeability is difficult to achieve, and cracking can occur. Additionally, the mere factor of time can also lead to the potential for slurry walls to degrade or deteriorate.

\subsubsection{Grout curtains}

Grout curtains are installed by injection of grout directly into the soil or by in situ mixing of soil. This technology is more costly to install than slurry walls, but the advantage is that grout curtains can be installed at an angle. This technique is limited to soils that have a hydraulic conductivity less than approximately $10^{-4}$ centimeters per second $(\mathrm{cm} / \mathrm{s}$ ) (Gerber and Fayer 1994). Care should also be taken when using Portland cement due to the occurrence of cracking from shrinkage, thermal stress from hydration reactions, and wet/dry cycling at arid sites.

\subsubsection{Sheet piling}

Sheet piling cut-off walls are constructed of precast interlocking sheets of steel, precast concrete, aluminum, or wood driven into the soil. The sheet piles are commonly installed to a depth of $12 \mathrm{~m}$ but can be successfully driven to an excess of $30 \mathrm{~m}$ (Gerber and Fayer 1994). These walls are very strong and can have a high chemical resistance (Pearlman 1999). Irregularly shaped walls can be installed, and minimal waste disposal is needed. The disadvantage with this technique is that the joints and base are vulnerable to leakage. To improve the sealing of the wall, grout can be injected at the joints.

\subsubsection{Vitrified barriers}

A vitrified barrier is a vertical cut-off wall created using electrodes that melt the vadose zone soil in situ (Gerber and Fayer 1994). Additional 
material is not needed, but the technique is limited to unsaturated soil and a depth of approximately $9 \mathrm{~m}$.

\subsubsection{Frozen barriers}

Frozen barriers can be used in a circumferential pattern to completely enclose a site, or they can be installed as an open barrier to redirect groundwater flow. No diaphragm walls, chemical, or other grouting material remains in the subsurface environment, thus making ground freezing an environmentally friendly method (Hass and Schafers 2005). Currently, the only limitation on depth of freezing is an economic one. The deeper one digs into the earth, the warmer it becomes and the more costly the refrigeration system required to create and maintain a frozen barrier becomes.

\subsection{Configurations of vertical barriers}

Site-specific conditions affect the configuration and the efficiency effects of a barrier wall. Sometimes the barriers can be installed at an angle resulting in an angled barrier that serves as the floor for the containment. Interior and exterior extraction wells can also be used in conjunction with barriers to maximize containment inside the barrier and capture leakage outside the barrier (USEPA 1996).

\subsubsection{Keyed and hanging vertical walls}

In most cases, vertical walls are keyed into a low permeability material below the contaminated zone. An alternative configuration would be a hanging wall that projects into the groundwater table and blocks the movement of lower density or floating contaminants (i.e., light nonaqueous phase liquids [LNAPLs]) (Mitchell and van Court 1997). Hanging walls are used at locations where the vertical barrier does not need to fully penetrate the aquifer (LNAPL sites). An illustration of keyed walls and hanging walls can be seen in Figure 1. 
Figure 1. a) Keyed and b) hanging vertical wall (after Rumer and Ryan [1995]).

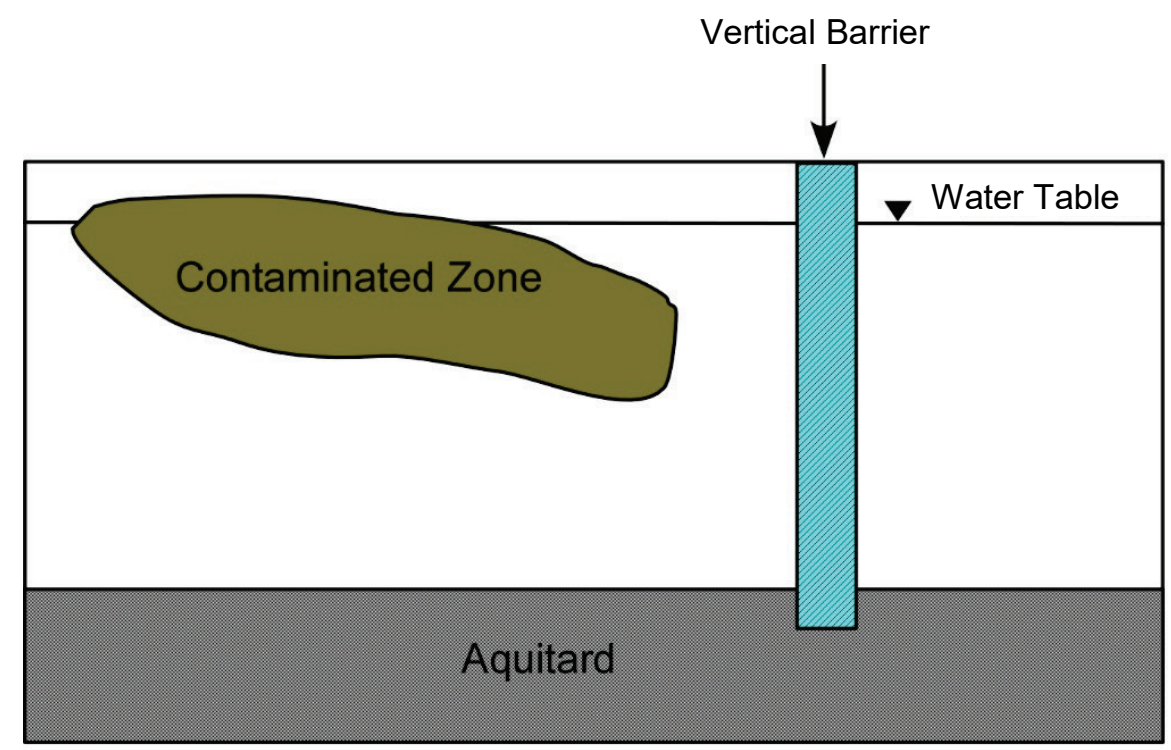

a)

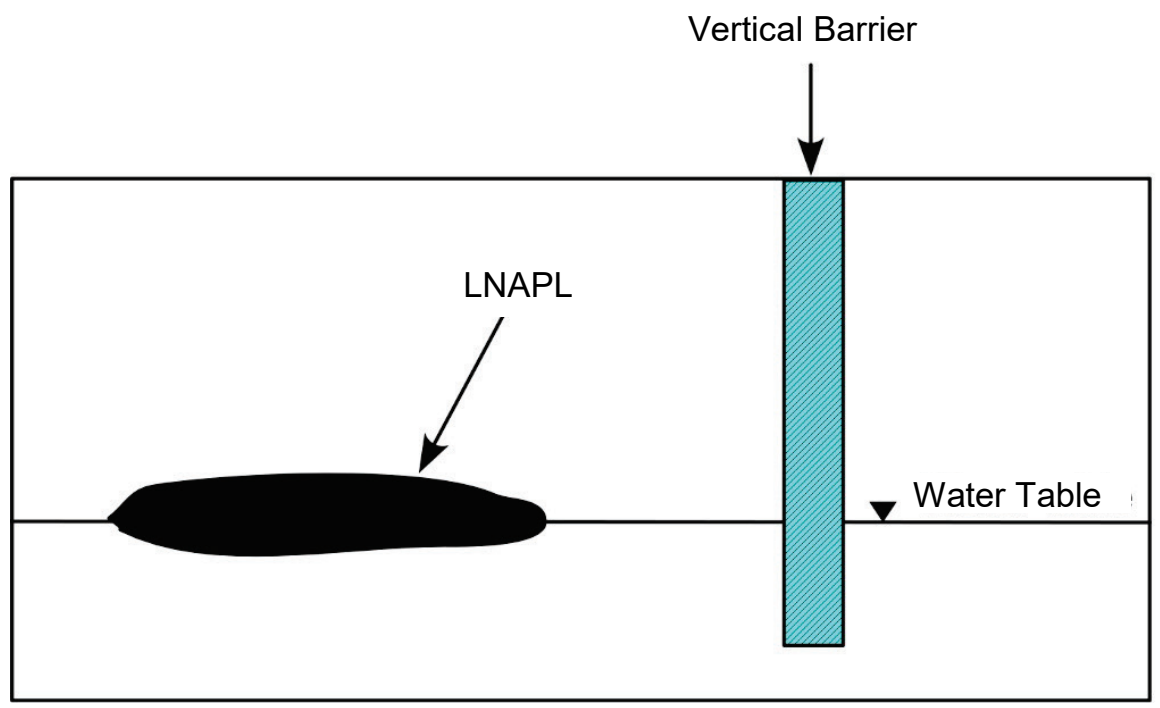

b)

\subsubsection{Circumferential barriers}

When installing a circumferential barrier, the spread of contaminations is to be avoided, in addition to restricting clean groundwater flow in to the contaminated zone (Mitchell and van Court 1997). For such a design to be effective, the barrier should be keyed into an underlying aquitard (Figure 2) unless a positive gradient can be maintained into the enclosed area. Extraction wells are shown in Figure 2, but circumferential barriers can also be used without having a pump-and-treat system installed. Groundwater extraction and treatment systems are often used in conjunction with circumferential barriers where the contaminated 
groundwater is extracted from within the wall and sent to treatment. This configuration decreases the volume of water needed to be treated. One of the most documented sites where a circumferential barrier design has been used is at the Gilson Road Superfund Site in Nashua, NH (USEPA 1987).

Figure 2. Circumferential vertical barrier (after Rumer and Ryan [1995]).
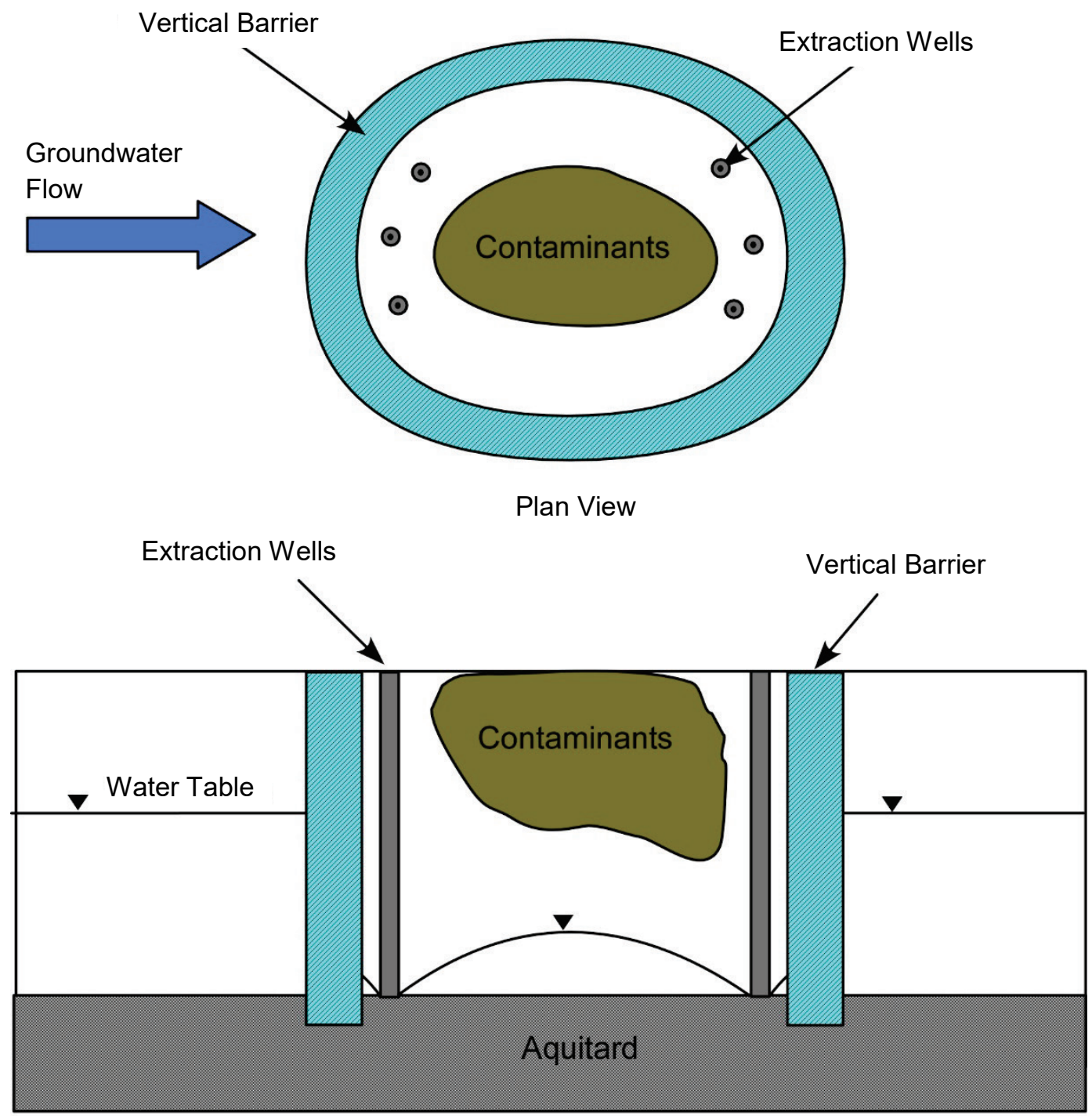

Section View

\subsubsection{Up- and down-gradient barriers}

An up-gradient barrier could be used to prevent clean groundwater flowing into a contaminated site whereas a downgradient barrier can be used to divert contaminated groundwater to an extraction point (Figures 
3-4). Up- and down-gradient barriers can also be used in combination with extraction wells. Using an up-gradient barrier in conjunction with a down-gradient pumping system can result in capturing downgradient contaminants. The well discharge rate can effectively be decreased, which in turn decreases the treatable volumes of water (Mitchell and van Court 1997; Anderson and Mesa 2006). A down-gradient wall in conjunction with down-gradient pumping system flushes contaminants through the site, and inflow from clean down-gradient groundwater is also avoided.

Figure 3. Up-gradient vertical barrier (after Rumer and Ryan [1995]).

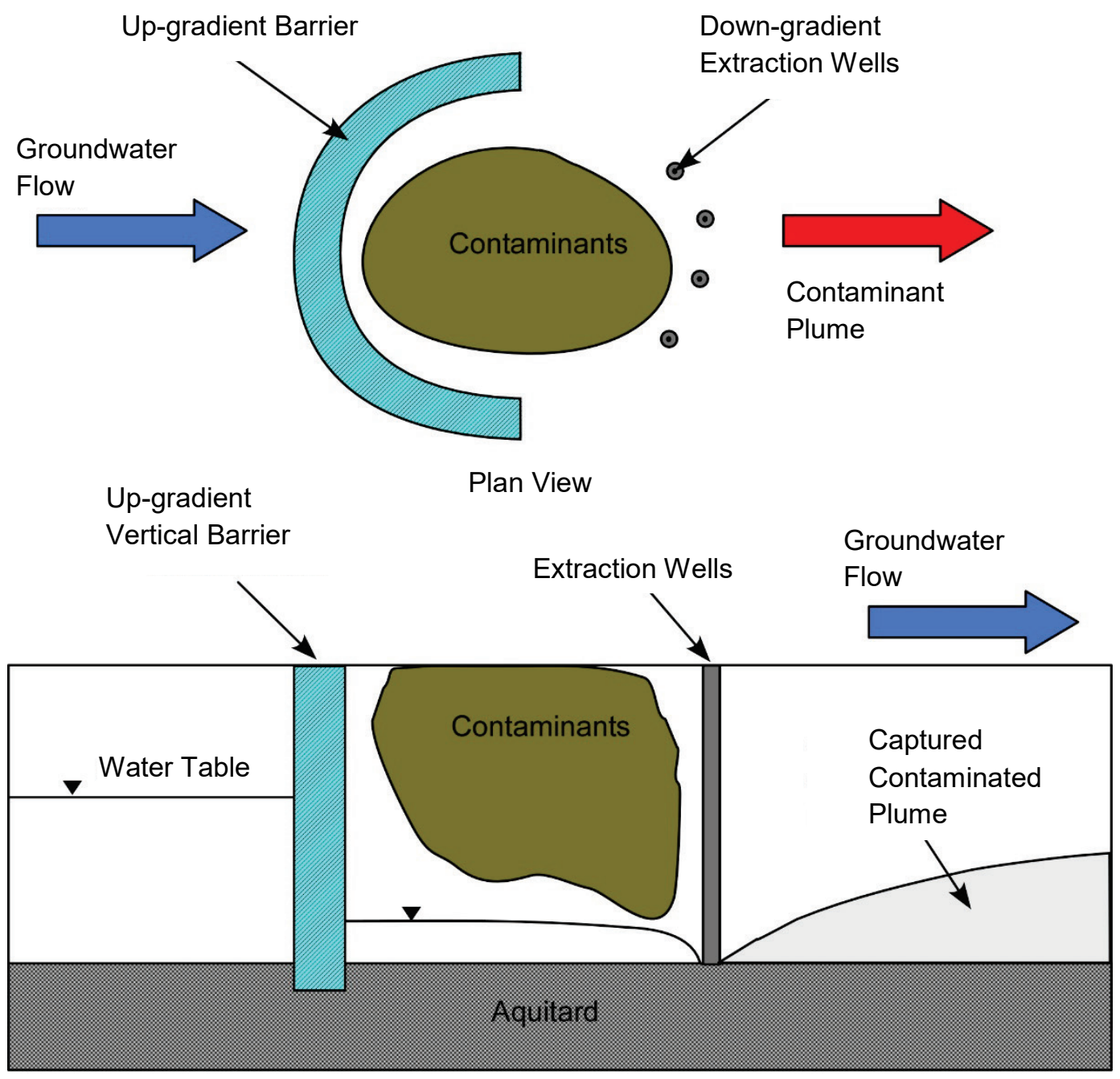

Section View 
Figure 4. Down-gradient vertical barrier (after Rumer and Ryan [1995]).

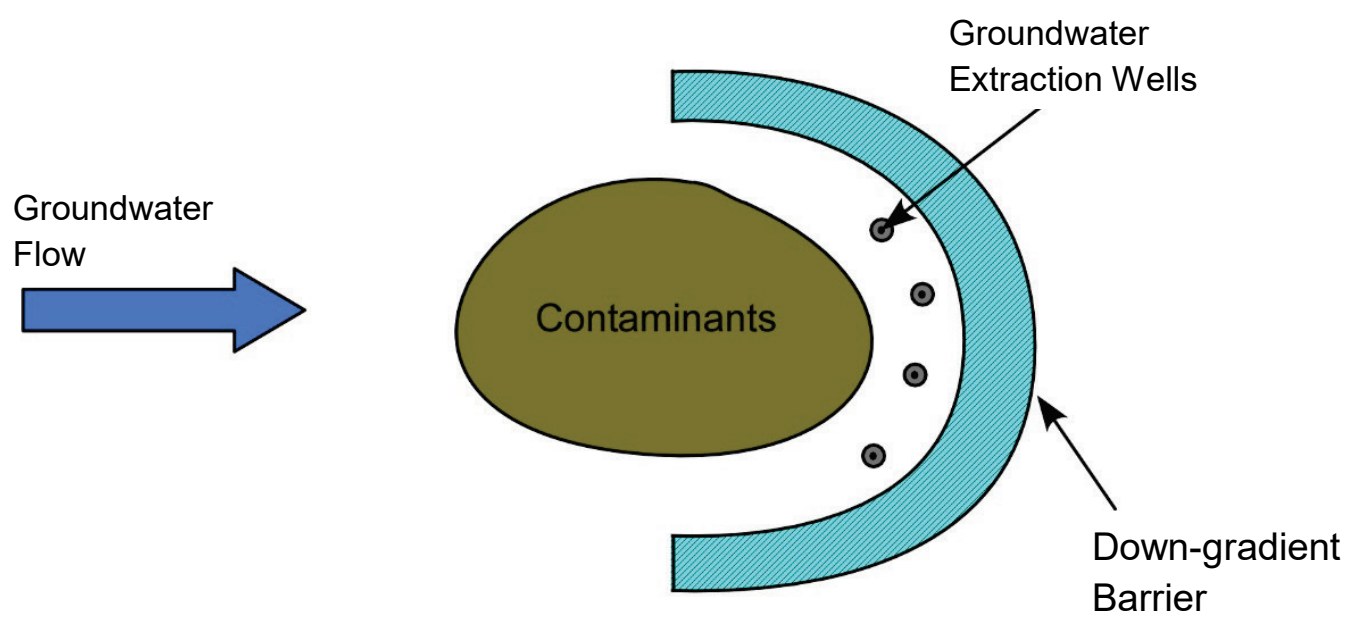

Plan View

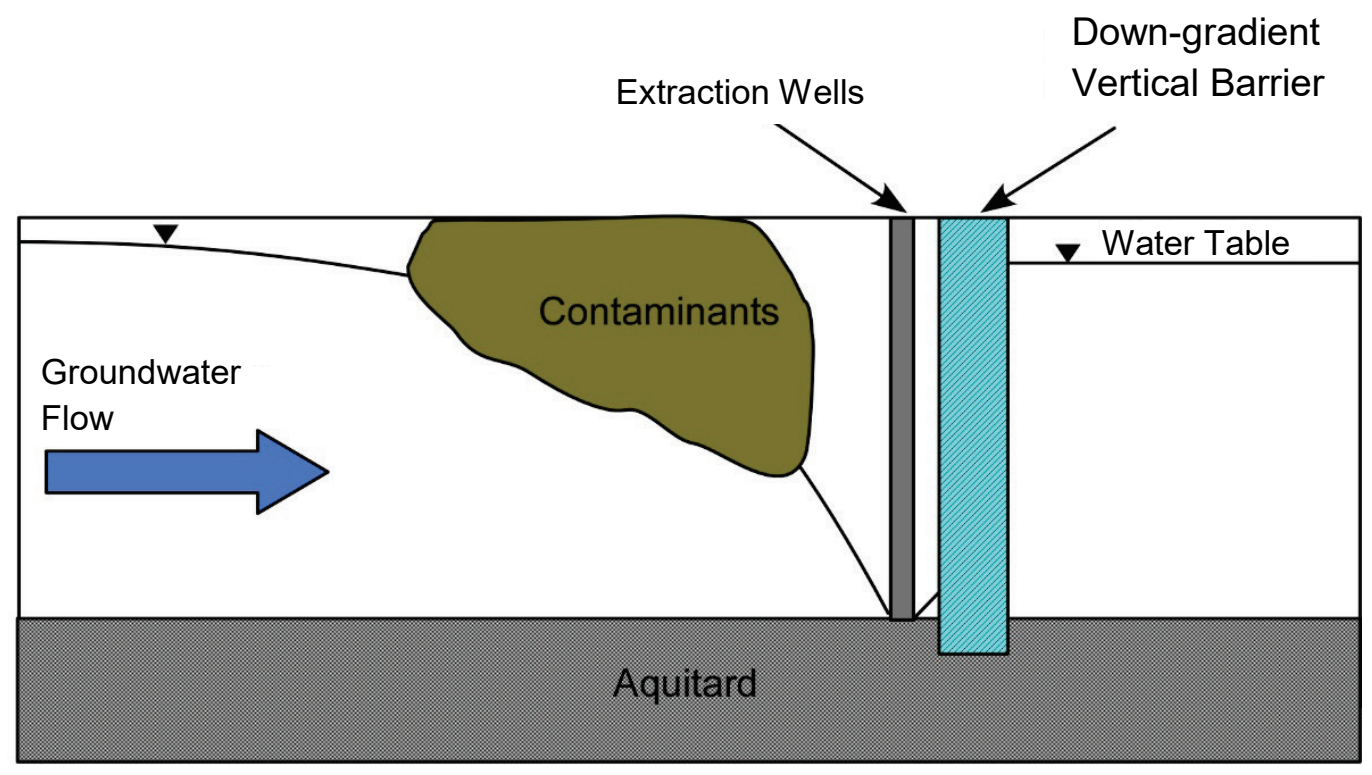

Section View

\subsection{Integrity of vertical barriers}

In general, hydraulic conductivity less than $10^{-7} \mathrm{~cm} / \mathrm{s}$ is accepted for slurry walls (Rumer and Ryan 1995). An industry-accepted permeability for soilbentonite barriers is $10^{-7} \mathrm{~cm} / \mathrm{s}$ (USEPA 1998c). Cement-bentonite and soilbentonite slurry trench walls have a hydraulic conductivity that ranges from $10^{-5}$ to $10^{-6}$ and $10^{-7}$ to $10^{-8} \mathrm{~cm} / \mathrm{s}$, respectively (Rumer and Ryan 1995). The permeability of grout barriers is approximately $5 \times 10^{-6} \mathrm{~cm} / \mathrm{s}$ (USEPA 1998c). Some field installations have recorded hydraulic conductivities of $10^{-8}$ to $10^{-10} \mathrm{~cm} / \mathrm{s}$ for sheet pilings (Smyth et al. 1997). In ice-rich soils, the hydraulic conductivity has been measured to $1 \times 10^{-9}$ 
$\mathrm{cm} / \mathrm{s}$ (extremely low) at a temperature of $-4{ }^{\circ} \mathrm{C}$ (McCauley et al. 2002). To assure a low hydraulic conductivity for the frozen barrier, it should be designed to have a core temperature that is $3{ }^{\circ} \mathrm{C}$ below freezing, thereby reducing the unfrozen water content of the frozen soil. Frozen barriers have a comparable hydraulic conductivity to other vertical barriers. 


\section{Artificial Ground Freezing}

In general, freezing occurs when a cold medium is in contact with the soil long enough for the pore water to freeze. Subsurface pipes are spaced around the contaminated zone, and a frozen soil mass is created around the freeze pipe over its full length. A continuous frozen barrier is created once the frozen masses of two adjacent pipes merge. The time to enclosure is site specific and depends on, for example, the soil type, soil moisture, and spacing of the pipes. Freezing pipes can also be installed at an angle to serve as containment beneath the contaminated soil.

\subsection{Conventional freezing techniques}

Two commonly used ground freezing techniques are the circulation coolant systems and the expendable refrigerant systems (Braun et al. 1979). A circulation coolant system, also referred to as a conventional system, consists of two independent closed circuits. One circuit is comprised of a pump, freeze pipes, and a heat exchanger; the other circuit contains a refrigerant such as ammonia, carbon dioxide or a fluorocarbon, compressor, a cooling system, and an evaporator (Karol 2003). A chilled brine, usually calcium chloride, circulates through the freeze pipes with a supply temperature of approximately $\mathrm{T}=-2 \mathrm{O}$ to $\mathrm{T}=-40{ }^{\circ} \mathrm{C}$ (Smoltczyk 2003). Stored ground thermal energy flows toward the pipes, heats the brine, resulting in a lowered ground temperature. The warmer brine flows back and gets re-cooled at the refrigerant plant. The expandable refrigerant system is an open system where refrigerant (liquid nitrogen or carbon dioxide) is used, and once the energy has been absorbed, it is lost to the atmosphere. This system is less complex system, and it uses liquid nitrogen $\left(\mathrm{LN}_{2}\right)$ from an on-site storage tank or a tank truck and feeds it into the freeze pipes (Karol 2003). The vaporization temperature of $\mathrm{LN}_{2}$ is $\mathrm{T}=-196^{\circ} \mathrm{C}$. Heat is transferred when it rises through the pipes. Once circulated through the pipes, the nitrogen is released to the atmosphere. The $\mathrm{LN}_{2}$ has a significantly higher cost per unit of heat extracted than with circulated brine. Due to the high cost of using $\mathrm{LN}_{2}$ systems, freezing with $\mathrm{LN}_{2}$ is only feasible when an immediate frozen wall is needed, if groundwater flow has a high velocity, for small volumes of soil, or for limited period of operation (Stoss and Valk 1979). 


\subsection{Thermosyphons}

Thermosyphons (also known as thermoprobes) are a much more energy efficient way of freezing the ground artificially. They have been used for foundation stabilization in continuous and discontinuous permafrost areas since 1960 (Richardson 1979). In 1996, thermosyphons were used to contain and immobilize radiological contaminated subsurface material at Oak Ridge National Laboratory, Tennessee, United States (Figure 5) (USDOE 1999). More recently, thermosyphons have successfully been used to prevent contaminant migration from tailings dams in Canada (Rykaart et al. (2015); Figure 6) and Russia (Optiz and Horne 2001). Furthermore, Duyvesteyn (2011) has applied for a patent using thermosyphons to create freezing barriers for in situ ore leaching.

Figure 5. Thermosyphon system for hazardous waste containment at Oak Ridge National Laboratory, Tennessee.

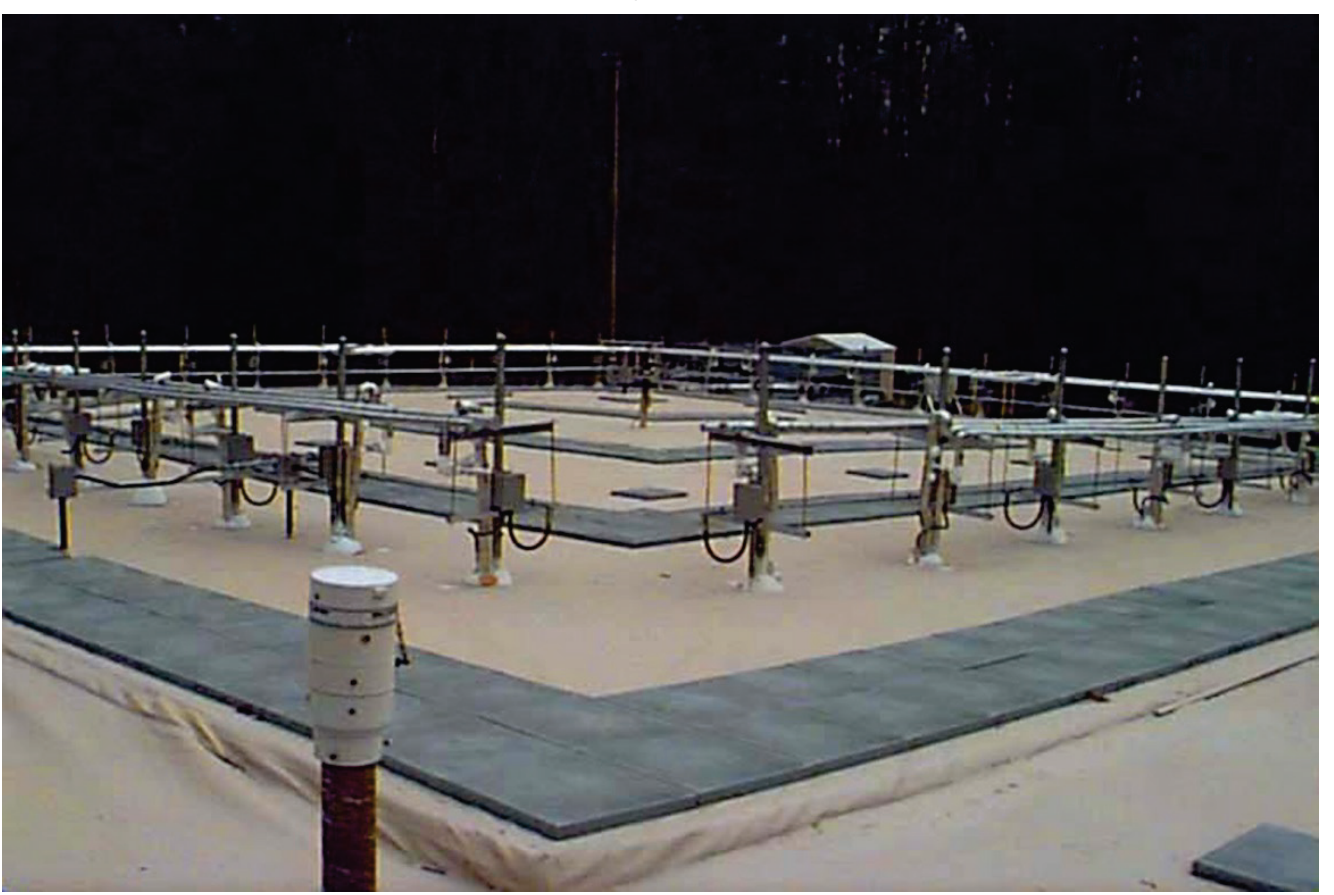


Figure 6. Thermoprobes at the Long Lake Outlet Dam, Ekati Diamond Mine, Northwest Territory, Canada.

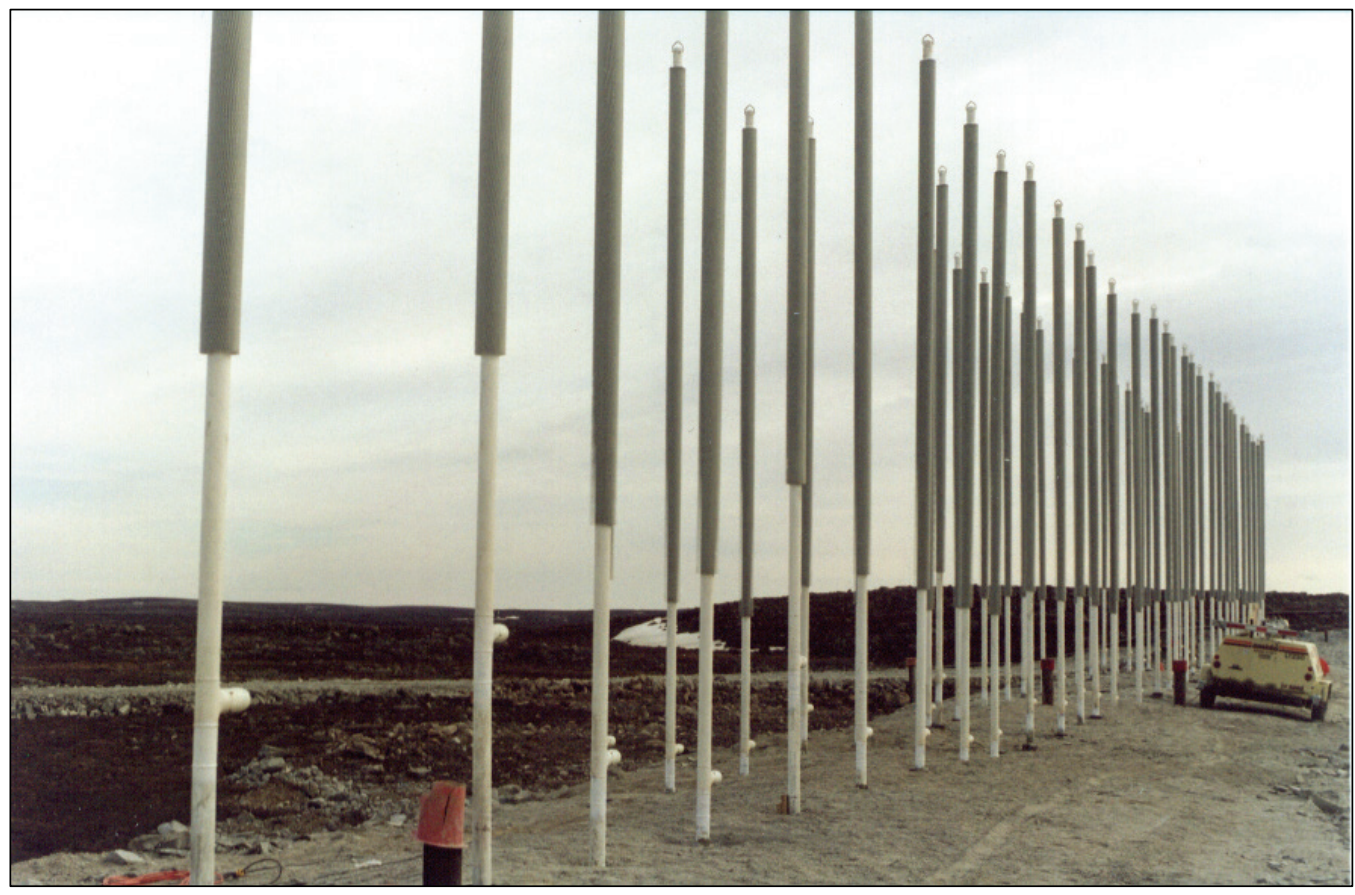

Thermosyphons are passive pressurized sealed pipes that are installed with one end buried (evaporator) and one end exposed to the air (condenser) (Figure 7). The pipe is charged with a working fluid so that there are only liquid and vapor phases of that fluid inside the pipe. When the air temperature is less than the ground temperature, the vapor condenses in the condenser and causes the liquid to build in the evaporator. Condensation releases heat in the condenser, and boiling absorbs heat in the evaporator. Vapor from boiling rises to the condenser, and the condensate liquid returns to the evaporator by gravity. The cycle continues as long as the air is colder than the soil in contact with the evaporator. 
Figure 7. Illustration of a passive thermosyphon.

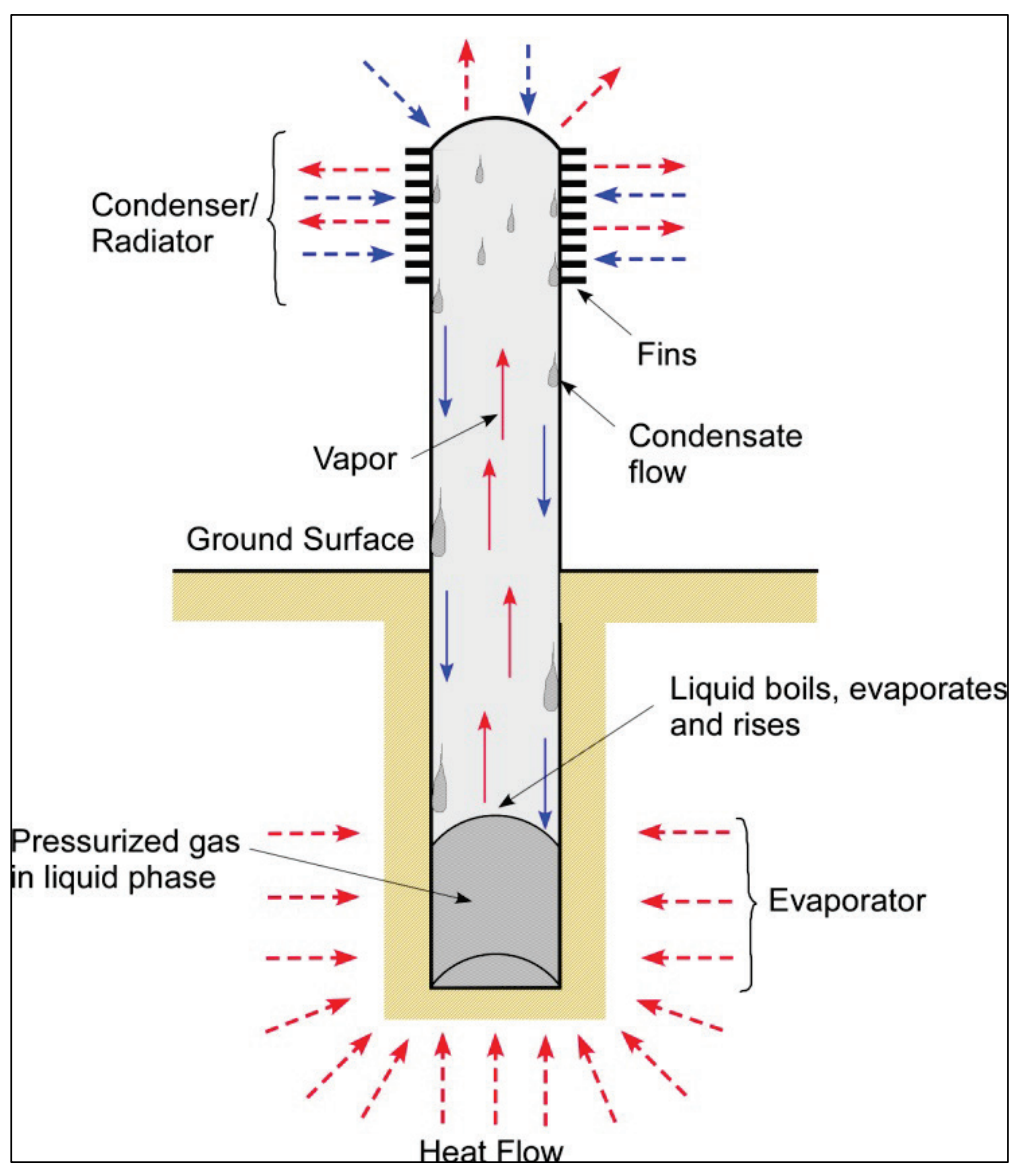

Passive thermosyphons function without external power and require air temperatures that are colder than ground temperatures to function. In warm climates, thermosyphons can be linked to a heat pump resulting in energy costs lower than conventional freezing techniques. These units are referred to as active thermosyphons. The passive and the active techniques can be combined into a hybrid system. The hybrid system functions without power when air temperatures are sufficiently low (i.e., below freezing). Once ambient temperatures rise above freezing, the active system, using power, is implemented. It is not uncommon to use the hybrid system for installations where faster freezing is needed.

\subsection{Design of a frozen barrier}

When constructing a successful artificial freezing barrier, care needs to be taken to achieve a complete impermeable wall. In general, geology and groundwater conditions need to be suitable for artificial ground freezing to be successful (Sanger and Sayles 1979). Braun et al. (1979) state that hydrology and geology are the most important factors for site constraints. 
To design a ground freezing system, specific site information is needed such as geology, hydrogeology, soil index properties, thermal and mechanical characteristics, and information on contaminant type and location. The soil or rock needs to be water-saturated, freezing cannot affect adjacent structures (heave), and groundwater velocities need to be slow enough for the frozen wall to be formed (Sanger and Sayles 1979). The frozen wall should be placed outside the contaminated zone to allow formation from groundwater that is free from contamination (Andersland et al. 1996a).

Jones (1981) reported that the spacing of freeze pipes when conventional brine coolants are used is $0.75-1.5 \mathrm{~m}$. The freeze-pipe spacing used for mine shafting in Germany is $1.28 \pm 10 \% \mathrm{~m}$ (Tatiya 2005). Greater spacing of up to $3 \mathrm{~m}$ can be used if a longer freeze time can be allowed (Dash 1991).

\subsection{Technology evaluation}

\subsubsection{Advantages with frozen barriers}

There are several advantages to using frozen barriers to contain contaminants. Frozen barriers can readily be deployed at most any site provided that the freezing tubes can be installed. The barrier can be established whether the materials adjacent are soil, rock, or other solids. These materials usually cause problems when techniques such as grouting or driving sheet piling are used (Hass and Schäfers 2006). If the materials' temperature can be lowered to below freezing, then they can be incorporated into the barrier. For example, a frozen barrier can be implemented where numerous pipes and wires transect the barrier without having to remove the pipes and wires. Details of the pipe and wire materials should be known so that the barrier is not breached because of pathways created by the material(s).

Frozen barriers are self-healing if ruptured by an earthquake or blast-type event (Dash 1991; Long and Yarmak 2000). Moisture will flow into the cracks in a barrier and freeze the broken parts together. Typical barriers are on the order of $3.7 \mathrm{~m}$ thick, and it would take a severe ground displacement to cause a breach in a frozen barrier.

Barriers can be removed once the remediation is completed (Dash 1991; Andersland et al. 1996a). Essentially, the containment process is transient (i.e., thawing takes place once the source of chilling is removed). This 
allows conditions to return to "normal" without continued interference to the site hydrology and makes the technique environmentally friendly. Additionally, a frozen barrier can be installed at almost any depthhundreds of meters-and in nearly any configuration. The system is also versatile in that it can be used in any geologic formation or soil type containing sufficient pore moisture.

Because of the great thermal inertia of a frozen barrier, the barrier can stay frozen for a long time. Dash (1991) states that a frozen barrier can stay frozen from 6 months up to 2 years. Advantages and benefits of a frozen barrier with a hybrid thermosyphon system are listed in Table 1.

Table 1. Advantages and benefits of a hybrid thermosyphon system.

\begin{tabular}{|l|l|l|}
\hline Feature & Advantage & Benefit \\
\hline Long-term & 20 to 50+ year life & Radioactive treatment \\
\hline Benign cooling media & $\begin{array}{l}\text { Shallow or deep, vertical } \\
\text { or horizontal }\end{array}$ & Contains any contaminant \\
\hline Re-healable barrier & Re-freezes if soils shift & $\begin{array}{l}\text { Protects soil from further } \\
\text { contamination }\end{array}$ \\
\hline Thaw stable & Immune to power outages & Reliable \\
\hline $\begin{array}{l}\text { Works in saturated or } \\
\text { unsaturated soil }\end{array}$ & No need to add moisture & Versatile \\
\hline
\end{tabular}

\subsubsection{Disadvantages with frozen barriers}

This technology has limitations in unsaturated granular soils with low water content. To create an effective frozen barrier in a semiarid region with low water content $(3 \%-6 \%)$, water needs to be introduced (Andersland et al. 1996b). A clay additive, such as bentonite, can be used to attain a high degree of ice saturation.

As cited by Jessberger (Pimentel et al. 2010), the formation of the frozen barrier may be hindered by a high groundwater velocity. High velocity of groundwater flow can create ice erosion and result in thawing of a frozen barrier. Braun et al. (1979) state, "Running water is the natural enemy of ice." Ice erosion can be minimized by designing a barrier that is fully ice saturated and that has a barrier temperature less than the freezing point depression of the contaminant (Andersland et al. 1996b). Non-aqueous phase liquids, with their low solubility in water, do not depress the 
freezing point of water, and hence, no melting of the ice matrix occurs (Andersland and Ladanyi 1994).

To limit ice erosion, a careful study of the groundwater velocity is needed. When using conventional coolants, groundwater flow rates less than $2.3 \times 10^{-5} \mathrm{~m} / \mathrm{s}$ were documented by Sanger (1968) as an accepted upper limit for a single row of freeze pipes. Similarly, Braun et al. (1979) reported this limit to $1.7 \times 10^{-5} \mathrm{~m} / \mathrm{s}$. For saturated soils, Karol (2003) documented that artificial freezing can be done where the groundwater flow is less than $2.8 \times 10^{-5} \mathrm{~m} / \mathrm{s}$. In general, to address this problem, closer spacing, a second row of freeze pipes, or using a refrigerant with a lower temperature can be used in the design. For example, Braun et al. (1979) report that when groundwater flow is greater than $1.7 \times 10^{-5} \mathrm{~m} / \mathrm{s}$ and less than $3.5 \times 10^{-5} \mathrm{~m} / \mathrm{s}$, closer spacing of pipes and/or a second row of freeze pipes can be applied. They also report that when liquid nitrogen is used (in a cryogenic refrigeration system), groundwater flows with velocities up to $5.8 \times 10^{-4} \mathrm{~m} / \mathrm{s}$ can be frozen.

\subsubsection{Strengths and weaknesses of containment/remediation technologies}

Table 2 lists the strengths and weaknesses of containment/remediation technologies.

Table 2. Strengths and weaknesses of competing technologies (from Johnson et al. [2000]).

\begin{tabular}{|c|c|}
\hline Strengths & Weaknesses \\
\hline \multicolumn{2}{|l|}{ Ground Freezing using Thermosyphons } \\
\hline $\begin{array}{l}\text { Long-term functionality ( } 20 \text { to } 50+\text { years) } \\
\text { Re-healable barrier } \\
40 \text { years of experience } \\
\text { Applicable for deep applications } \\
\text { Low life-cycle costs } \\
\text { No use of anti-freeze cooling media } \\
\text { Ability to target freeze zone well below the } \\
\text { surface } \\
\text { Has been successfully used to contain } \\
\text { radionuclides }\end{array}$ & $\begin{array}{l}\text { Not a treatment technology (except for rapid } \\
\text { decaying contaminants) } \\
\text { Ongoing operating and maintenance costs }\end{array}$ \\
\hline \multicolumn{2}{|l|}{ Conventional Ground Freezing } \\
\hline $\begin{array}{l}\text { These companies are typically large and } \\
\text { well known } \\
\text { Low first costs } \\
\text { Experience in ground freezing }\end{array}$ & $\begin{array}{l}\text { Large capitalization in short-term } \\
\text { equipment } \\
\text { Use of anti-freeze coolants } \\
\text { Short-term applications }\end{array}$ \\
\hline
\end{tabular}




\begin{tabular}{|c|c|}
\hline Strengths & Weaknesses \\
\hline \multicolumn{2}{|l|}{ Re-healable barrier } \\
\hline \multicolumn{2}{|l|}{ Microbial Bio-barriers } \\
\hline $\begin{array}{l}\text { Re-healable barrier } \\
\text { No ongoing energy costs }\end{array}$ & $\begin{array}{l}\text { Does not function above water table } \\
\text { Unproven in full-scale applications } \\
\text { Ongoing operational costs }\end{array}$ \\
\hline \multicolumn{2}{|l|}{ Sheet Piling } \\
\hline $\begin{array}{l}\text { Proven technology } \\
\text { Predictable installation cost } \\
\text { No operating costs }\end{array}$ & $\begin{array}{l}\text { Limited to shallow applications } \\
\text { Limited to installation in driveable soils } \\
\text { Not re-healable }\end{array}$ \\
\hline \multicolumn{2}{|l|}{ Slurry Walls } \\
\hline Proven technology & $\begin{array}{l}\text { Limited to shallow applications } \\
\text { Large volumes of cuttings } \\
\text { Not re-healable } \\
\text { Intrusive }\end{array}$ \\
\hline \multicolumn{2}{|l|}{ Ground Injection } \\
\hline $\begin{array}{l}\text { Proven technology } \\
\text { Applicable at great depths }\end{array}$ & $\begin{array}{l}\text { Limited predictability for accurate } \\
\text { placement } \\
\text { Not re-healable }\end{array}$ \\
\hline \multicolumn{2}{|l|}{ Pump, Treat, and Inject } \\
\hline $\begin{array}{l}\text { Proven technology } \\
\text { Facilitates treatment of treatable } \\
\text { contaminants }\end{array}$ & $\begin{array}{l}\text { High operational and maintenance costs } \\
\text { Operationally intensive }\end{array}$ \\
\hline \multicolumn{2}{|l|}{ In Situ Vitrification } \\
\hline Treatment technology & $\begin{array}{l}\text { Limited to shallow applications } \\
\text { Expensive } \\
\text { Not compatible with high moisture soils }\end{array}$ \\
\hline \multicolumn{2}{|l|}{ Membrane Walls } \\
\hline Proven technology & $\begin{array}{l}\text { Limited to shallow applications } \\
\text { Large volumes of cuttings } \\
\text { Not re-healable } \\
\text { Intrusive }\end{array}$ \\
\hline
\end{tabular}




\section{Installation and Technology Comparison Cost}

Installation costs of subsurface barriers vary depending on construction methods, type of barrier, and most importantly, on the unique site conditions. The cost of a frozen barrier depends on the size and the service of the barrier, in addition to the climatic zone of the installation. For active systems, electrical costs are a factor. In colder climates, costs may be reduced if a passive system or a hybrid system is installed, which will reduce the electricity demand. When installations are performed in or adjacent to hazardous materials, the site safety and health considerations during installation can eclipse the drilling costs. Total costs can be reduced by using wider pipe spacing, but this would result in a slower freezing to closure, so it may not be suitable if time is a factor.

\subsection{Frozen barrier cost}

When installing a system to create a frozen barrier using thermosyphons, it is important to take into account the climatic zone of the installation. For example, in this report it is demonstrated that for an installation in a cold climatic zone such as Fairbanks, AK, where the annual average air temperature is $-3{ }^{\circ} \mathrm{C}$, no additional energy may be needed to maintain the barrier once the barrier is frozen. In contrast, an active system would have to be implemented at a warmer location. Once the ground is frozen, energy required to maintain it in a frozen state on a daily basis is substantially lower than that required for initial freezing. Hybrid systems can be installed at locations where the air temperature is below freezing during the winter for passive operation in winter and active operation in the summer. Figure 8 shows annual air temperatures and average winter air temperatures (December, January, and February) for all states in the United States. In total, there are 25 states that have winter average temperatures below freezing, with Alaska being the coldest $\left(-16.3^{\circ} \mathrm{C}\right)$. In addition to Alaska, the following states have winter average temperatures colder than $-5{ }^{\circ} \mathrm{C}$ : Iowa, Maine, Michigan, Minnesota, Montana, North Dakota, New Hampshire, South Dakota, Vermont, Wisconsin, and Wyoming. These states would be locations where hybrid systems could be installed to decrease electrical costs. 


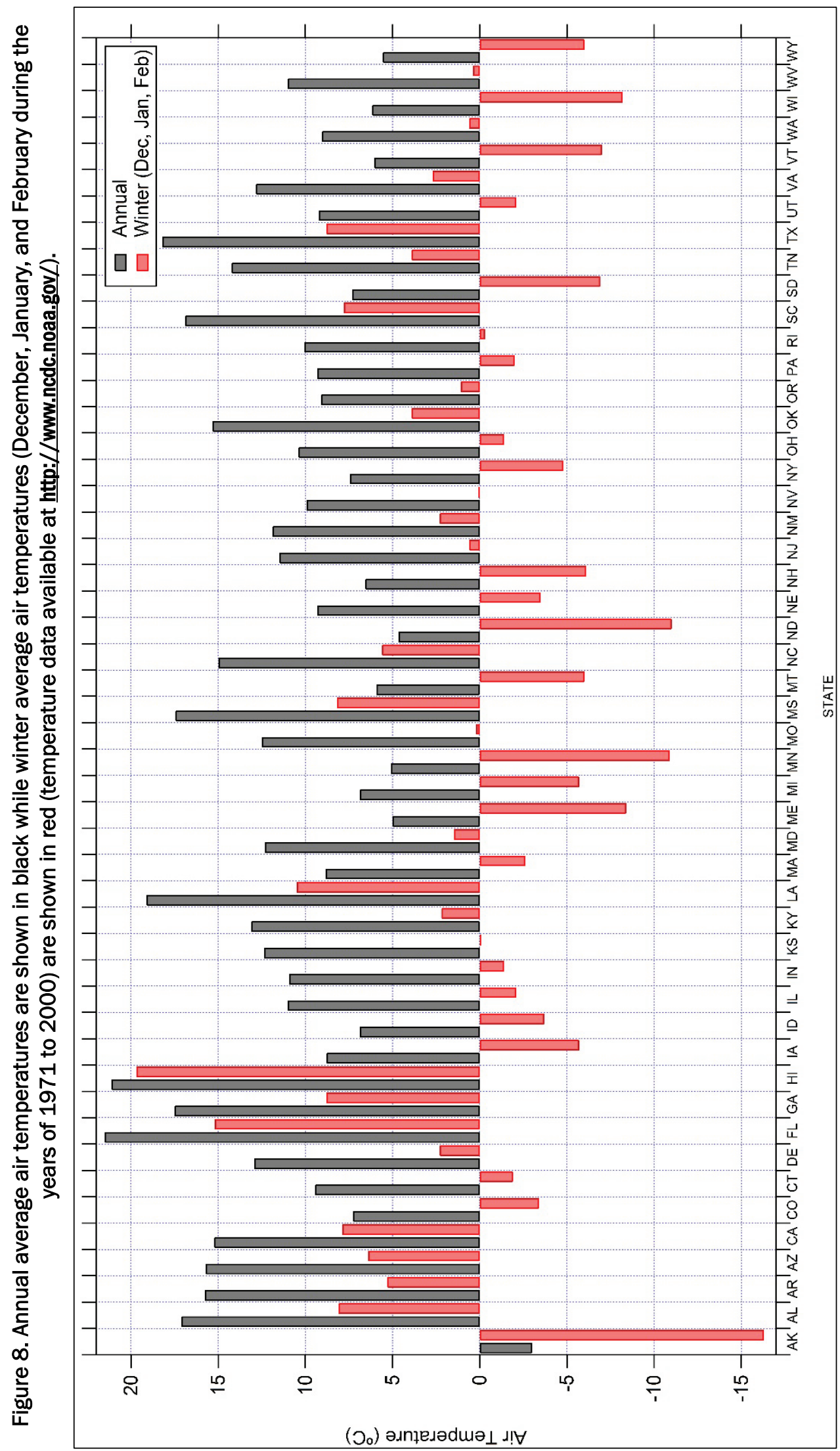




\subsubsection{Passive system}

A passive system can be installed where climatic conditions are low enough to drive the thermosyphons. Figure 9 illustrates a cost analysis for a $5.5 \mathrm{~m}$ deep barrier with a $2 \mathrm{~m}$ spacing of $6.5 \mathrm{~m}^{2}$ sized thermosyphons and an overall barrier thickness of $4 \mathrm{~m}$. This cost could vary $15 \%$ more or less from the calculated cost and includes materials for barrier, drilling, and temperature monitoring. At some locations, both insulation and a membrane are needed in addition to the barrier. The additional cost of a membrane and insulation has also been estimated in Figure 9. The installed average cost for a smaller passive barrier $\left(550 \mathrm{~m}^{2}\right)$ without insulation and membrane is approximately $\$ 149 / \mathrm{m}^{2}$, and for a larger barrier $\left(8,800 \mathrm{~m}^{2}\right)$ the cost is approximately $\$ 87 / \mathrm{m}^{2}$. This system requires limited maintenance, and no electricity cost is associated with the passive system.

Figure 9. Installation cost of a passive barrier with the black line representing the average cost and the gray field is the $15 \%$ varied cost from the average cost.

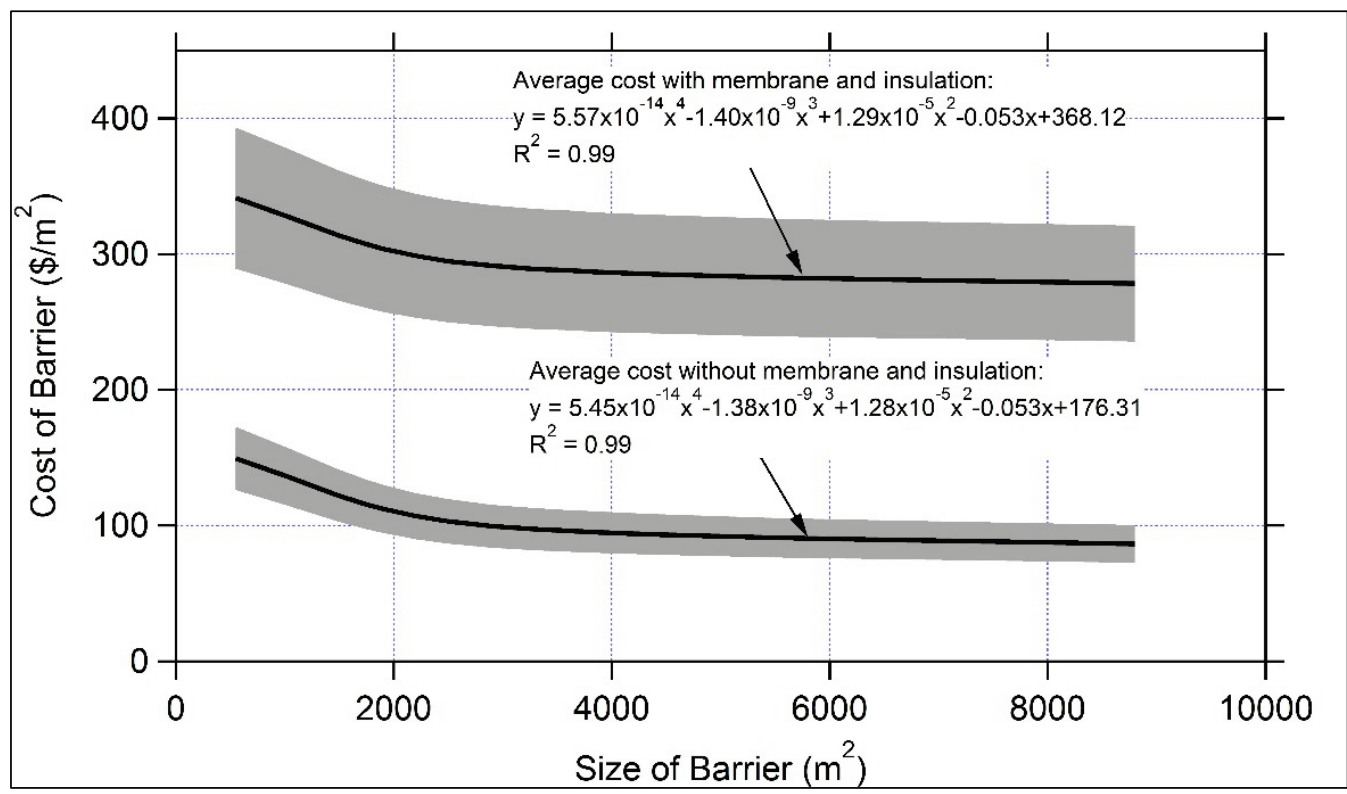

\subsubsection{Active system}

Frozen barriers can be used in warmer climate, such as Florida. They have successfully been implemented for containment of contaminants at Oak Ridge National Laboratory, Tennessee, and at Ft. Detrick, MD, where the average annual air temperature is 15 and $12{ }^{\circ} \mathrm{C}$, respectively.

The estimated cost to install an active system ranges from an average cost of approximately $\$ 781 / \mathrm{m}^{2}$ for a small-sized barrier $\left(2,000 \mathrm{~m}^{2}\right)$ to approximately $\$ 392 / \mathrm{m}^{2}$ for a larger-sized barrier $\left(32,000 \mathrm{~m}^{2}\right)$ (Figure 10). 
The barrier is based on a $20 \mathrm{~m}$ deep barrier with $2 \mathrm{~m}$ spacing of the thermosyphons and an overall barrier minimum thickness of $4 \mathrm{~m}$. This cost could vary $\pm 15 \%$ from the calculated cost and includes materials for the barrier, drilling, temperature monitoring equipment, insulation, surface membrane, and a freezedown technician.

Figure 10. Installation cost of an active barrier with the black line representing the average cost and the gray field is the $\pm 15 \%$ range from the average cost.

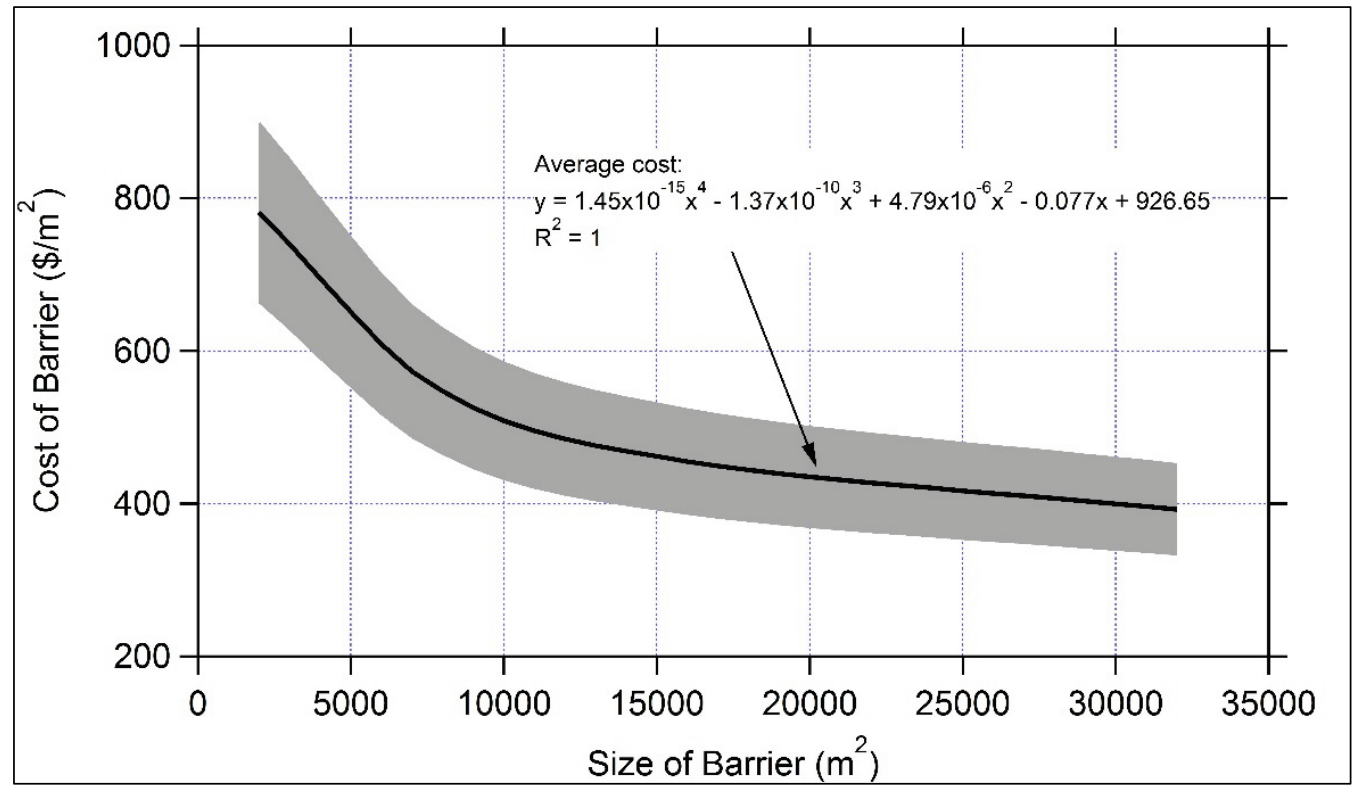

At the Oak Ridge National Laboratory installation, the freezedown electrical power for a $3.7 \mathrm{~m}$ thick wall was $73.4 \mathrm{kWh} / \mathrm{m}^{2}$. At other installation sites, this quantity could range from $15 \%$ less to $40 \%$ more due to soil or rock type and water content. Therefore, the average calculated freezedown electrical power is estimated at $83 \mathrm{kWh} / \mathrm{m}^{2}$. The electricity maintenance power for a system running actively (i.e., 24/7/365) is approximately $122 \mathrm{kWh} / \mathrm{m}^{2} /$ year.

Electricity costs in the United States vary depending on nearby energy sources. The average electricity costs range between a low of 6.46 cents/kWh (Idaho) and a high of 34.98 cents/kWh (Hawaii) (USEIA 2012) (Figure 11). The average commercial electricity cost is 9.57 cents $/ \mathrm{kWh}$ (excluding Hawaii). To reduce electricity usage of hybrid and active systems, the system can run intermittently when desired barrier thickness has been reached (Jones 1981). 


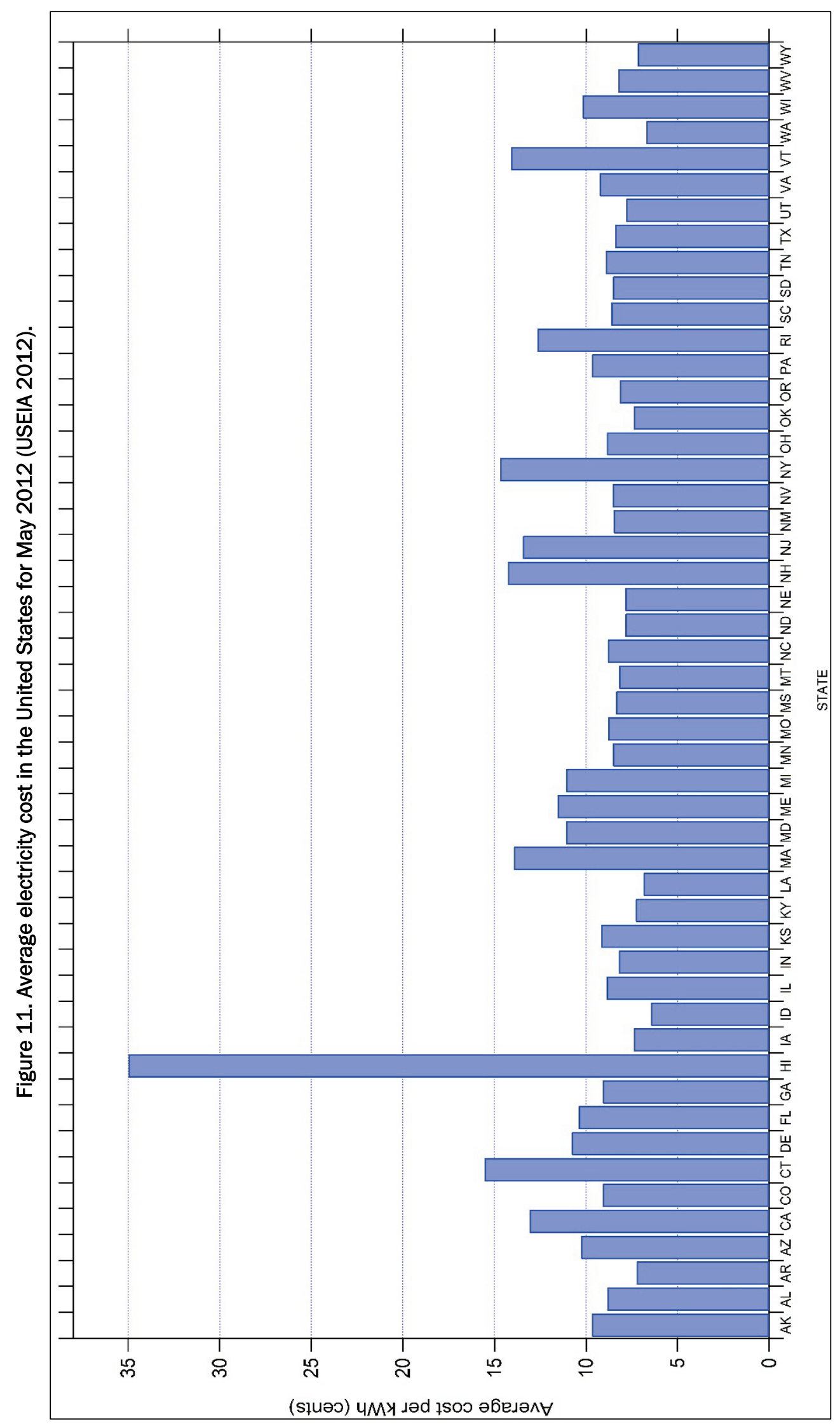




\subsection{Case studies}

In this section, existing slurry wall installations are used as examples for where frozen barriers could have been implemented. Also provided are costs following the general guidelines as stated in Section 4.1.2 for installing an active system at that specific location. The historical costs were converted to 2012 costs using the Engineering News Records Construction Cost Index History (www.enr.com).

\subsubsection{Lipari landfill, Mantua, NJ}

The Lipari Landfill in Mantua, NJ, was used from 1958 to 1971 as an active dump site for industrial and household wastes. A containment system was completed in 1984 and consisted of an underground slurry wall encircling a $64,750 \mathrm{~m}^{2}$ area. The wall is 9 to $15 \mathrm{~m}$ deep, $0.75 \mathrm{~m}$ wide, approximately $880 \mathrm{~m}$ long, and prevents ground water from leaving or entering the landfill (USACE 1994). The installation cost of the slurry wall was $\$ 2.38 \mathrm{M}$ and the total cost, which included a synthetic membrane, was approximately $\$ 4.95 \mathrm{M}$ (Ramage 1988). The cost of the membrane alone was approximately $52 \%$ of the total cost of the slurry wall installation. The area along the length of the slurry wall totals $10,560 \mathrm{~m}^{2}$, resulting in a cost of $\$ 225 / \mathrm{m}^{2}$ for the slurry wall installation (excluding the membrane).

Freezing the periphery of the landfill (a length of $880 \mathrm{~m}$ and an average depth of $12 \mathrm{~m}$ ) would cost about $\$ 514 / \mathrm{m}^{2}$. The annual electricity cost to maintain a $4 \mathrm{~m}$ frozen barrier in New Jersey would be approximately $\$ 174 \mathrm{~K}$.

\subsubsection{Sylvester/Gilson Road Superfund site, NH}

The Sylvester/Gilson Road site is a Superfund site located in Nashua, NH. The site was used for illegal dumping, which was first discovered in 1970, and it has been estimated that the site was used for hazardous waste disposal for 5 years (USEPA 1998a). The remedial application at this site consisted of a pump-and-treat system, vertical barrier wall, cap, and soil vapor extraction system. The 20-acre site is enclosed by a $1,220 \mathrm{~m}$ long and 30 m deep slurry wall (USEPA 1998b). A 40-mil high density polyethylene synthetic cap covers the area inside the slurry wall. The cost for the slurry wall and the geomembrane totaled $\$ 5.4 \mathrm{M}$. Since the cost of the geomembrane itself was unavailable, it is assumed the cost would be approximately $52 \%$ of the total cost of slurry wall installation (based on 
the percentages calculated from the Lipari Landfill example above). The installation cost of the slurry wall along the length of the barrier is estimated at $\$ 71 / \mathrm{m}^{2}$ (excluding the cost for the cap).

The cost to install a 1,220 $\mathrm{m}$ long and $30 \mathrm{~m}$ deep $\left(36,600 \mathrm{~m}^{2}\right)$ frozen wall would cost approximately $\$ 416 / \mathrm{m}^{2}$. The annual electricity cost to maintain a $4 \mathrm{~m}$ thick wall in New Hampshire is approximately $\$ 627 \mathrm{~K}$. Because the average winter air temperature in New Hampshire is $-6.1^{\circ} \mathrm{C}$, the electricity cost can be reduced if a hybrid system is installed. However, for this particular example, since the installation costs of the frozen wall exceed the slurry wall costs, the fact that New Hampshire has an average winter air temperature below $0^{\circ} \mathrm{C}$ is a moot point.

\subsubsection{The West Valley Demonstration Project Act, West Valley, NY}

In 2008, a slurry wall was installed to prevent water infiltration at the radioactive waste disposal area at West Valley, NY. The total cost for the slurry wall and a 30-mil thick geomembrane was approximately $\$ 5.6 \mathrm{M}$ (Mann et al. 2009; Sullivan et al. 2009). It is estimated that the geomembrane installation cost is approximately $52 \%$ of the total cost (estimated from the Lipari Landfill geomembrane installation). The wall was $290 \mathrm{~m}$ long and $5.5 \mathrm{~m}$ deep $\left(1,595 \mathrm{~m}^{2}\right)$, resulting in a cost of $\$ 1,685 / \mathrm{m}^{2}$ along the length of the barrier.

Installing a frozen barrier at this location would cost $\$ 828 / \mathrm{m}^{2}$. In the state of New York, annual electricity and maintenance cost would average approximately $\$ 31 \mathrm{~K}$ to keep a $4.0 \mathrm{~m}$ thick barrier frozen.

\subsubsection{The NW Natural "Gasco" site, Portland, OR}

A groundwater/DNAPL source control removal action was evaluated for the NW Natural "Gasco" site in Portland, OR, that included a cost analysis of several remediation technologies. The estimated cost to install a $380 \mathrm{~m}$ long and $20 \mathrm{~m}$ deep $\left(7,600 \mathrm{~m}^{2}\right)$ slurry wall is $\$ 6.5 \mathrm{M}$ (excluding nonconstruction costs, such as permitting and contingency costs) (Anchor Environmental 2007). Based on the area of the slurry wall, the cost is $\$ 855 / \mathrm{m}^{2}$ to install.

To install a $7,600 \mathrm{~m}^{2}$ frozen barrier at this site would cost $\$ 569 / \mathrm{m}^{2}$. The average yearly electricity cost would be approximately $\$ 79 \mathrm{~K}$ to maintain a $4 \mathrm{~m}$ thick frozen barrier in Oregon. 


\subsubsection{Cost comparison of case studies}

Often, there are several techniques that can be used to form a subsurface barrier at a site to contain aqueous contaminants, and the chosen technique, or combination thereof, to be deployed will be determined by an economic analysis. In other cases, the economic analysis is flawed due to the fact that all of the techniques do not produce equal results. In the construction industry, when one absolutely has to contain a tunnel or a shaft below the water table, ground freezing is the method that is known to work. Likewise, that is why the Japanese government deployed a frozen barrier at the crippled Fukushima Daiichi nuclear plant that is approximately $1500 \mathrm{~m}$ long and $30 \mathrm{~m}$ deep. At Fukushima, there is a myriad of cables, pipes, and conduits below the ground that must be sealed, too. No other system can positively seal like the frozen barrier.

The cost comparison between existing slurry walls and the installation cost of active thermosyphons presented herein shows a wide range of installation costs (Table 3). The slurry wall cost was the least expensive at the Sylvester/Gilson Road Superfund Site in New Hampshire whereas a frozen barrier at this location would have cost nearly 2.3 times more. However, another example showed it would cost approximately $\$ 828 / \mathrm{m}^{2}$ to install a frozen barrier at the West Valley Demonstration Project Act, West Valley, NY, while the cost for the slurry wall installation was almost twice as expensive. There will be annual electricity costs when installing a frozen barrier. However, at the West Valley installation, the annual cost is only approximately $\$ 31 \mathrm{~K}$. Therefore, the frozen barrier can operate for approximately 45 years (excluding inflation costs) before reaching the total cost of the slurry wall installation. A similar situation exists for the NW Natural Gasco Site, where the frozen barrier can operate for approximately 28 years before attaining the total cost of the slurry wall installation. Note that the frozen barrier cost is estimated for a $4 \mathrm{~m}$ thick wall that would result in a total thickness, in some cases, close to five times thicker than the slurry wall (thereby offering greater protection). 
Table 3. Cost comparison between slurry wall and frozen barrier case study installations.

\begin{tabular}{|l|c|c|c|}
\hline & $\begin{array}{c}\text { Slurry Wall } \\
\left(\$ / \mathrm{m}^{2}\right)\end{array}$ & $\begin{array}{c}\text { Frozen Barrier } \\
\left(\$ / \mathrm{m}^{2}\right)\end{array}$ & $\begin{array}{c}\text { Electricity Cost } \\
\text { Frozen Barrier } \\
\left(\$ / \mathrm{m}^{2} / \text { year }\right)\end{array}$ \\
\hline $\begin{array}{l}\text { Lipari Landfill } \\
\text { Mantau, NJ }\end{array}$ & 225 & 514 & 16 \\
\hline $\begin{array}{l}\text { Sylvester/Gilson Road Superfund } \\
\text { Site, Nashua, NH }\end{array}$ & 71 & 416 & 17 \\
\hline $\begin{array}{l}\text { West Valley Demonstration Project } \\
\text { Act, West Valley, NY }\end{array}$ & 1,685 & 828 & 19 \\
\hline $\begin{array}{l}\text { NW Natural Gasco Site } \\
\text { Portland, OR }\end{array}$ & 855 & 569 & 10 \\
\hline
\end{tabular}




\section{Pilot Study}

\subsection{Site description}

A frozen barrier was demonstrated at Fort Wainwright, Fairbanks, AK, in July 2011 - September 2012. The mean annual air temperature in Fairbanks is $-3{ }^{\circ} \mathrm{C}$ with average highs of $23{ }^{\circ} \mathrm{C}$ in July and average lows of - $28{ }^{\circ} \mathrm{C}$ in January (Shulski and Wendler 2007). Soils consist of tan silt and windblown loess near the surface and grey silt at depths below $1.4 \mathrm{~m}$. This site is underlain with permafrost at a depth of approximately $9 \mathrm{~m}$.

The system was installed in July 2011 as an active system using a refrigeration unit. After 62 days, the active system was turned off, and the passive system was initiated. The test consisted of six thermosyphons installed in line, spaced at $1.5 \mathrm{~m}$ intervals, totaling a width of $7.5 \mathrm{~m}$ (Figure 12).

Figure 12. Installation layout.

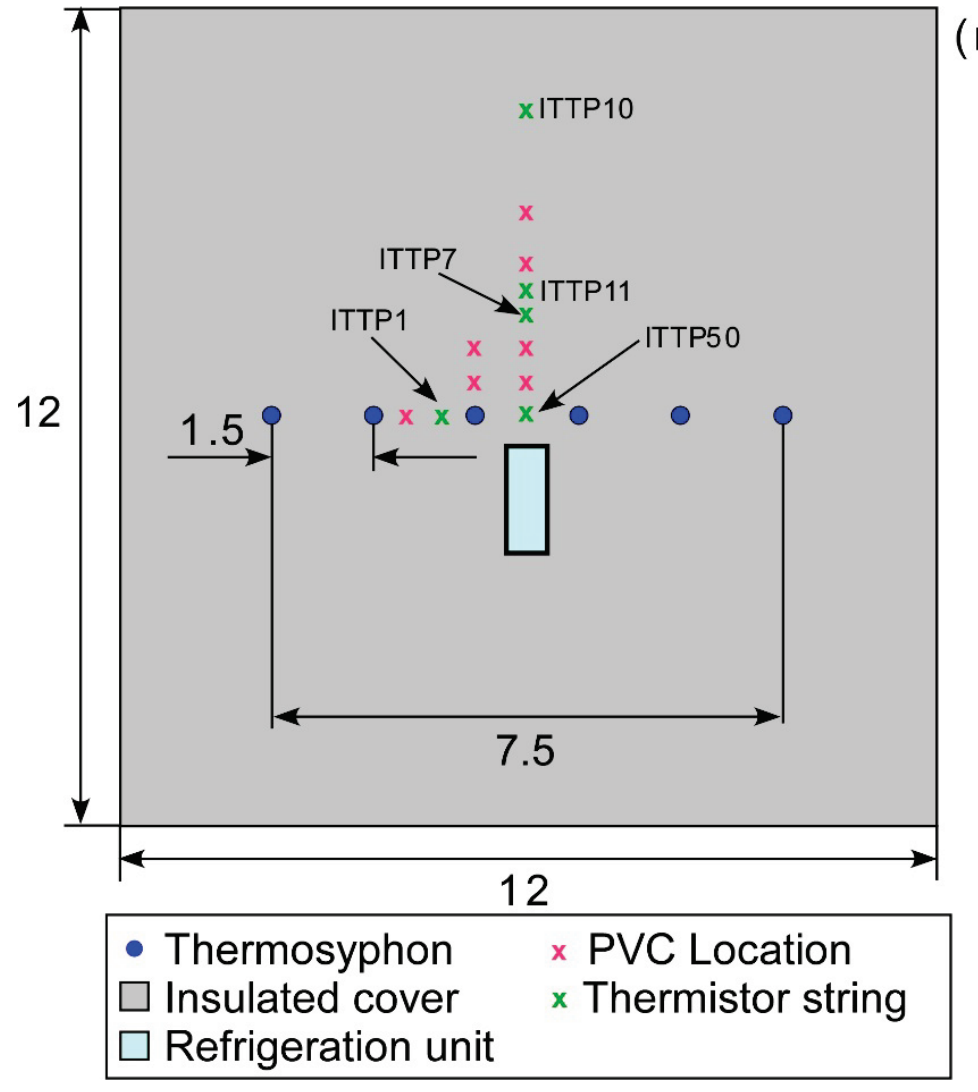

$(\mathrm{m})$

The ground surface was insulated using $0.15 \mathrm{~m}$ of extruded polystyrene (Figure 13), and a 12-mil membrane was placed on top to preclude surface water from infiltrating the insulated zone. In addition, the black-colored 
membrane was covered with sand to decrease heating of its surface by solar radiation. This design was used to ensure the freeze barrier would extend from the permafrost up to the ground surface and to limit heat transfer to the upper portion of the barrier.

For colder locations where contaminants are deeper than the seasonal thaw, insulation is not needed. Also, unless a high infiltration of rainfall is expected, the cover can be omitted in the design as well. At more temperate and warmer sites, the need for this type of protection depends on the depth of contaminants and expected rainfall infiltration. Furthermore, the insulation could be limited to only a strip wide enough to cover the thickness of the desired barrier (centered over the barrier). A complete installation can be seen in Figure 14.

Figure 13. Insulation installation.

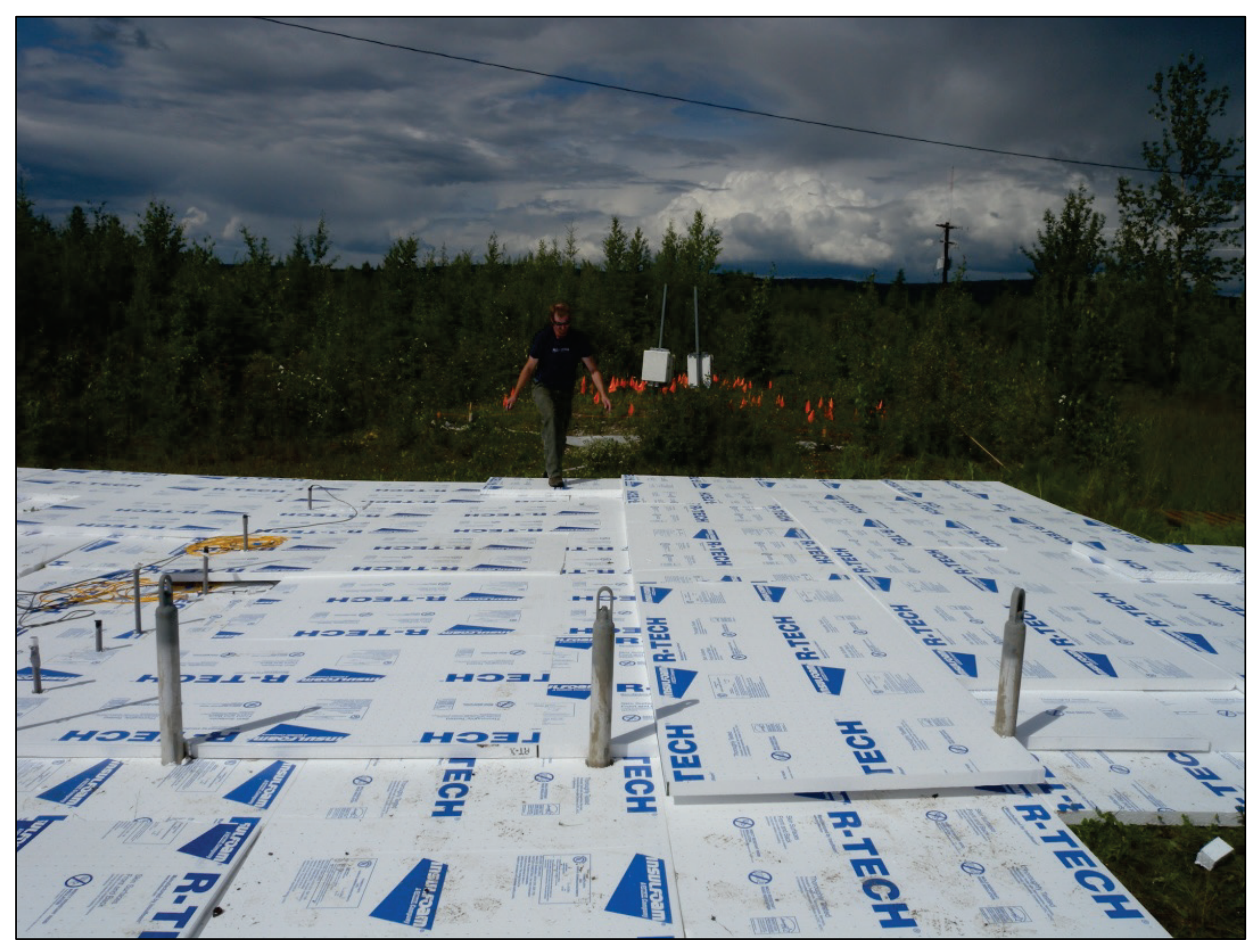


Figure 14. Complete installation of the hybrid thermosyphons and refrigeration unit.

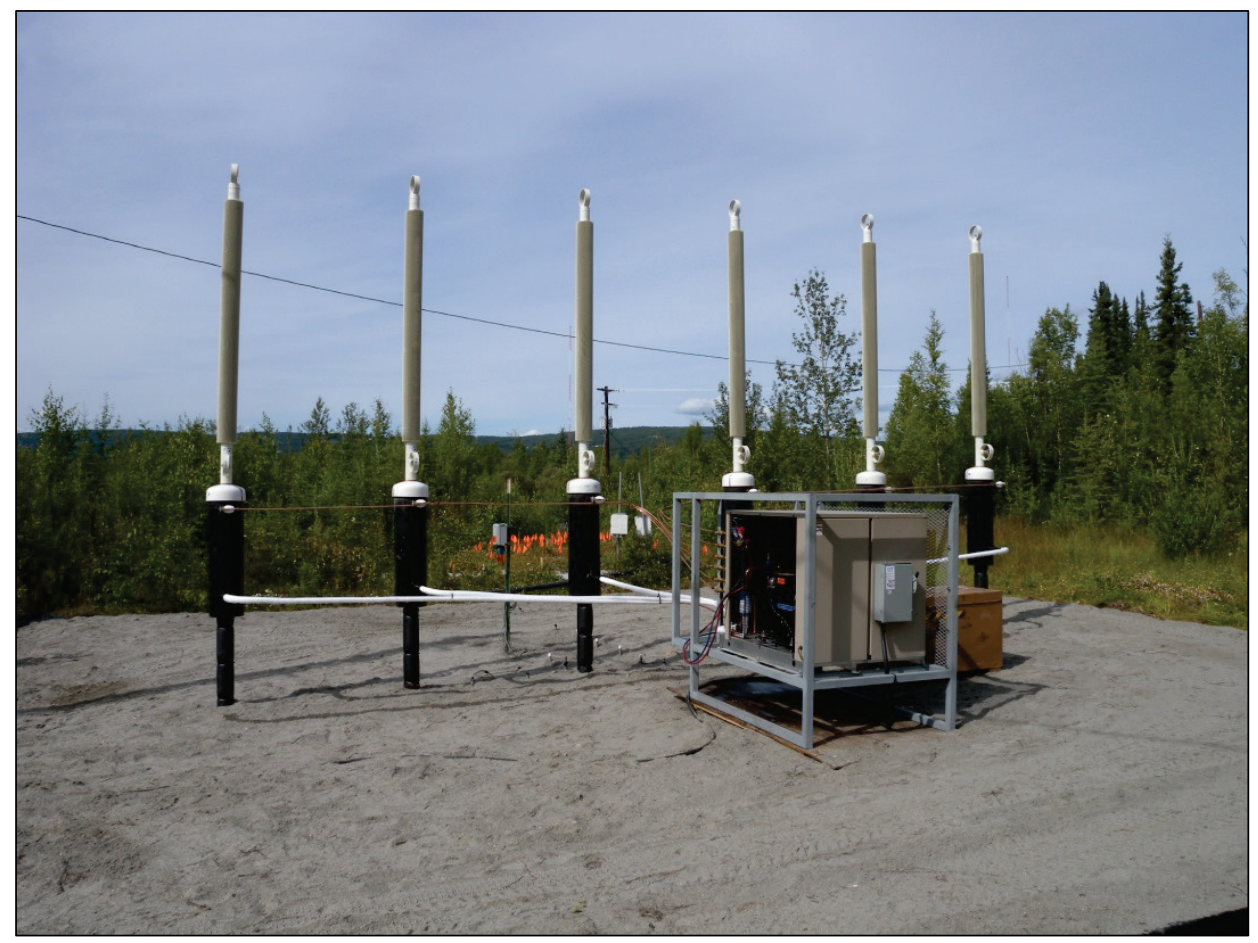

\subsection{Ground temperature measurements}

To monitor the performance of the frozen barrier, ground temperature was measured with thermistor strings. The freezing front advances (or retreats) through time, resulting in a need to monitor the ground temperature at different distances from the barrier and also at different depths. Therefore, thermistor tubes (or casings) and schedule 80 PVC pipes with a nominal diameter of $19.1 \mathrm{~mm}$ were installed for optimal use of the available thermistor strings.

During thawing, six specially ordered thermistor strings from BeadedStream were used and logged by a DL330 data logger. One string, ITTP50, was $15.2 \mathrm{~m}$ long with thermistors at $0,0.6,1.2,1.8,2.4,3.0,4.6$, 6.1, 7.6, 9.1, 10.7, 12.2, 13.7, and $15.2 \mathrm{~m}$ below the ground surface (where $\mathrm{o}$ is the insulation/ground interface). The other four strings were $10.7 \mathrm{~m}$ long and had thermistors placed at o, o.6, 1.2, 1.8, 2.4, 3.0, 4.6, 6.1, 7.6, 9.1, and $10.7 \mathrm{~m}$ below the ground surface (Figure 15). These strings were placed in ITTP1, ITTP7, ITTP10, and ITTP11 (Figure 16) and recorded ground temperature continuously. ITTP10 was placed at a sufficient distance from the line of thermosyphons to not be affected by the freezing front. This string is referred to as the "control" string in the following text. Unfortunately, the ITTP 50 hole was drilled just short of $15.2 \mathrm{~m}$ deep; 
therefore, the top sensor was not placed at the ground-insulation interface. To compare the top sensors with the other strings, an adjustment to this string was made by placing the second sensor at the insulation-ground interface. This resulted in the sensors for this string recording temperatures at $0,0.6,1.2,1.8,2.4,3.9,5.5,7.0,8.5,10.1,11.6,13.1$, and $14.6 \mathrm{~m}$ below the surface.

Figure 15. Thermistor location.

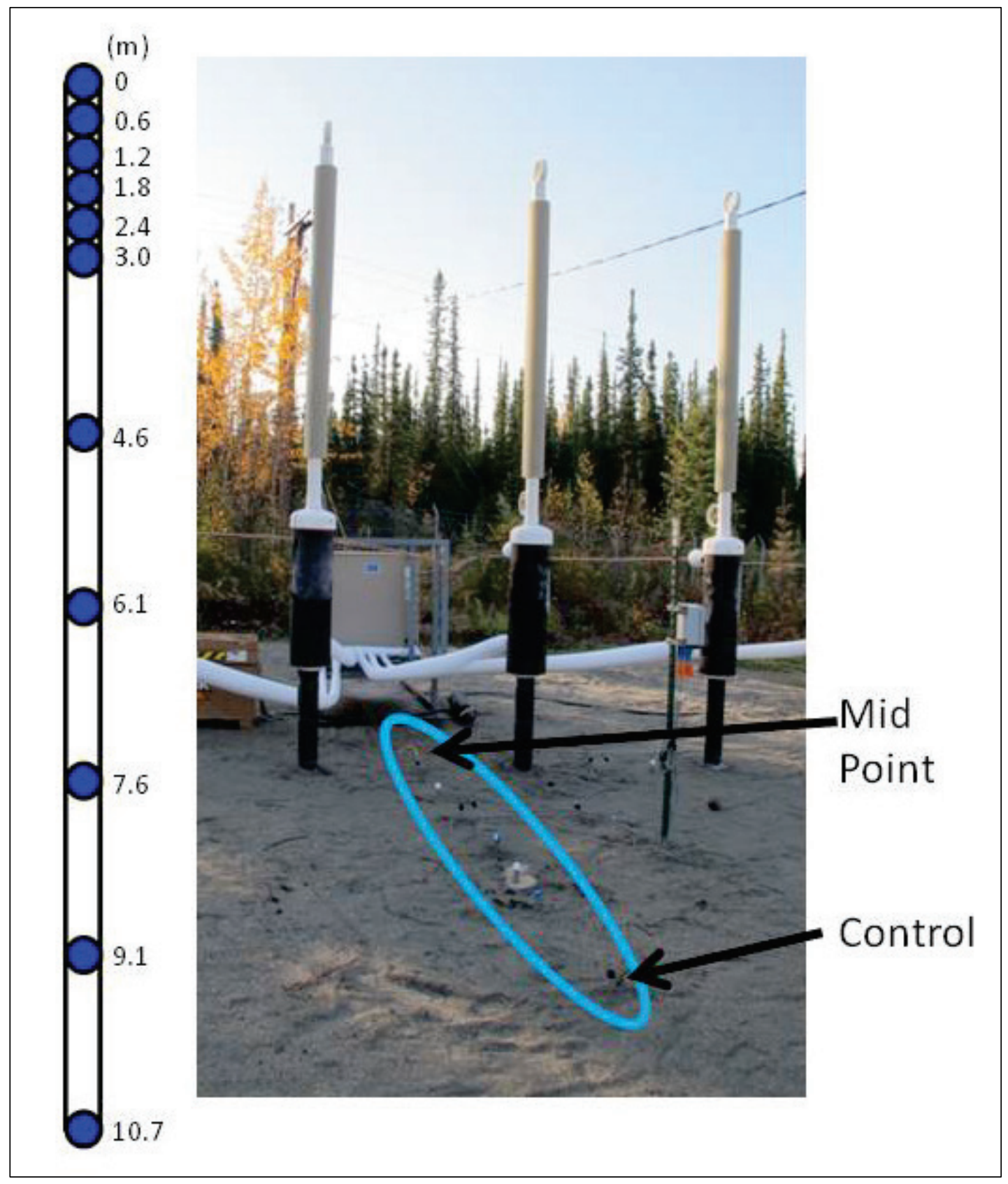


Figure 16. Layout of ground temperature monitoring locations.

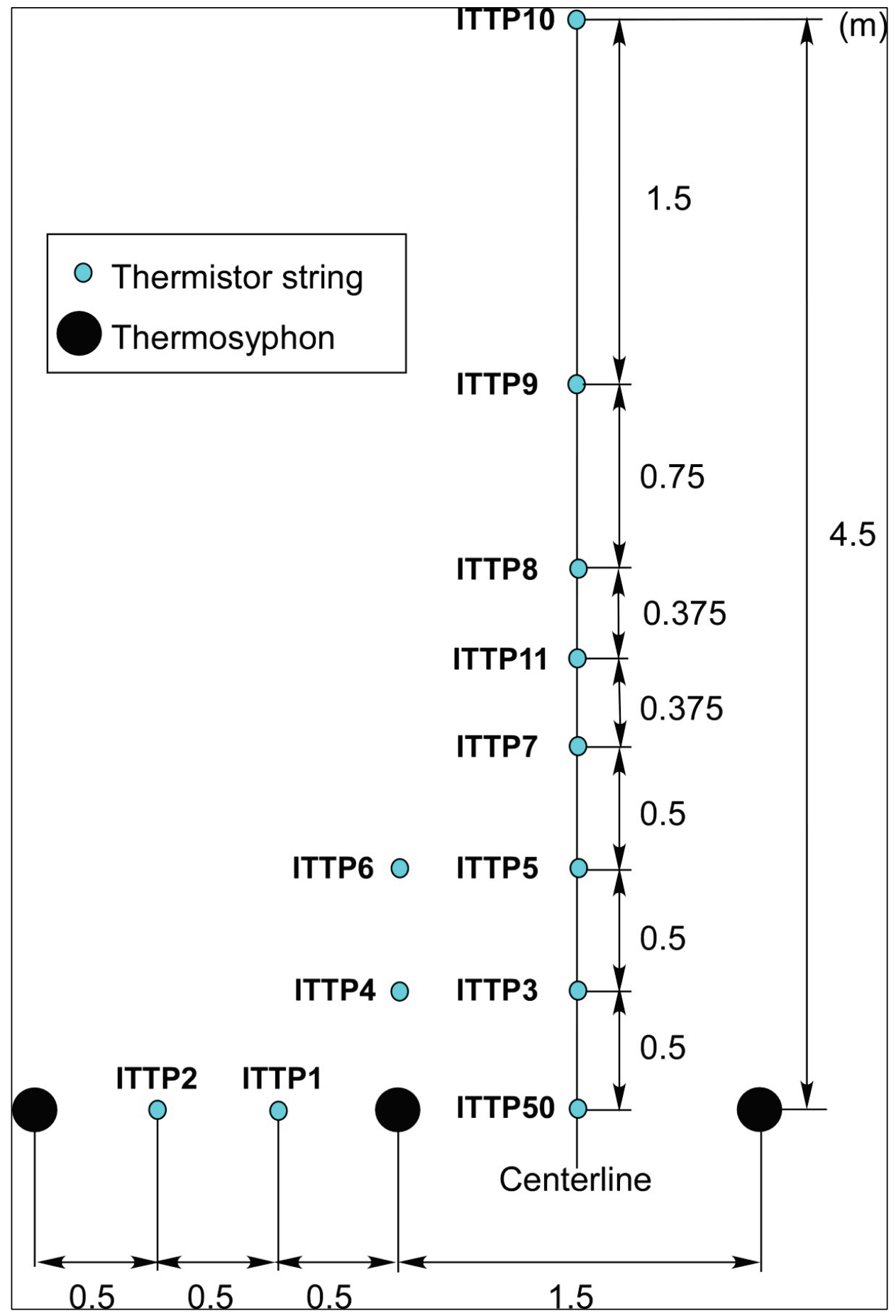

\subsection{Performance of barrier}

\subsubsection{Freezing to closure}

At the beginning of the demonstration, the maximum air temperature was $22{ }^{\circ} \mathrm{C}$. Forty-two days after the active thermosyphon system was started, 
the ground was completely frozen to a depth of $10.67 \mathrm{~m}$. The frozen soil was $1 \mathrm{~m}$ thick after 48 days of artificial freezing.

\subsubsection{Electricity cost}

For the 2-month active phase (mid-July to mid-September), the starting electricity usage was $144 \mathrm{kWh} /$ day and $118 \mathrm{kWh} /$ day when the active system was turned off (Figure 17). The average electricity usage was 132 $\mathrm{kWh}$ /day. Approximately $5,800 \mathrm{kWh}$ were used to reach freezing to closure, and an additional $792 \mathrm{kWh}$ were used to establish a $1 \mathrm{~m}$ wide barrier. It was estimated that the barrier was $9 \mathrm{~m}$ long and $7 \mathrm{~m}$ deep, which resulted in an electricity usage of approximately $92.16 \mathrm{kWh} / \mathrm{m}^{2}$ $\left(2.19 \mathrm{kWh} / \mathrm{m}^{2} /\right.$ day $)$ to get the barrier to closure and approximately 12.58 $\mathrm{kwh} / \mathrm{m}^{2}\left(2.10 \mathrm{kWh} / \mathrm{m}^{2} /\right.$ day $)$ to freeze it to a $1 \mathrm{~m}$ thick barrier.

Figure 17. Electricity usage and average air temperatures during the active phase.

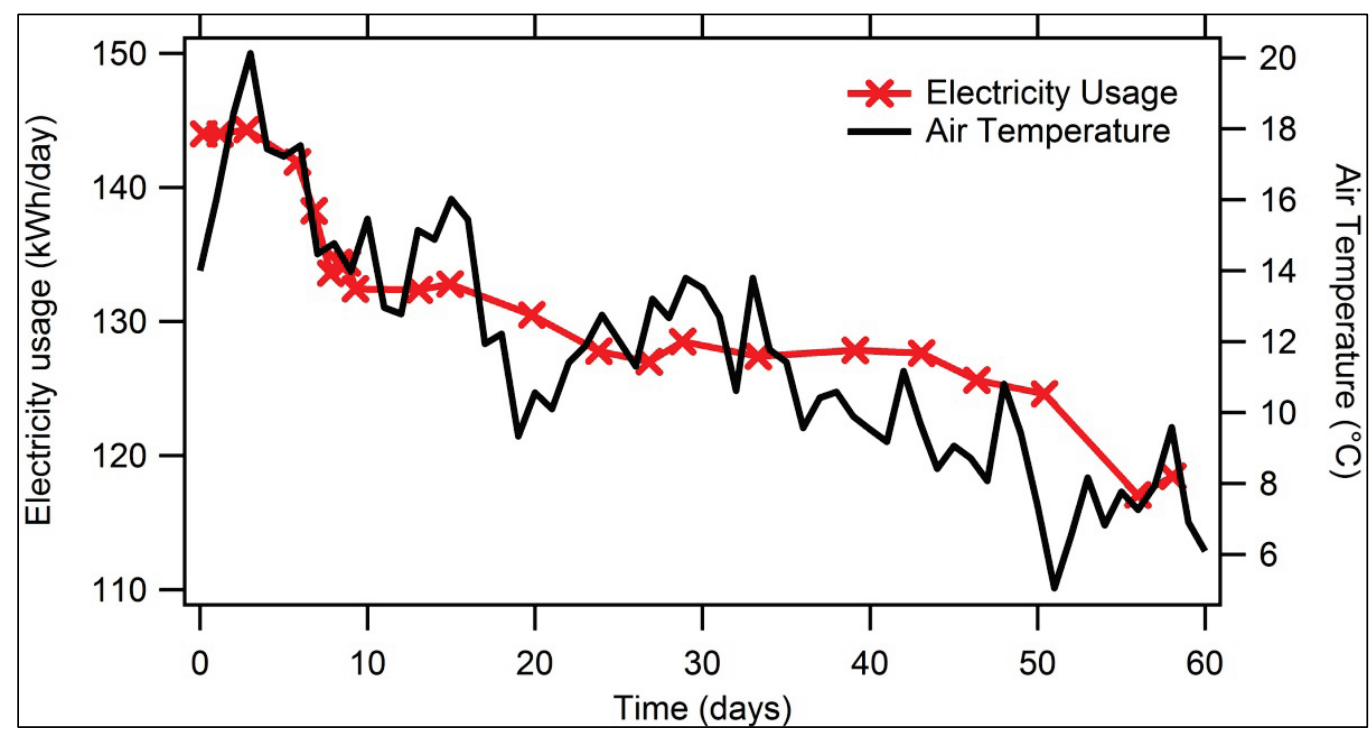

\subsubsection{Passive system}

When the active system was turned off in late fall, the passive system cooling started as soon as the air temperatures were below freezing. Although it took approximately 5 weeks until the passive system started cooling, the ground remained frozen during this time (Wagner and Yarmak 2012). The ground stayed frozen throughout winter, and once the air temperature was above freezing in late spring, the ground temperatures started to increase. Only the top $0.5 \mathrm{~m}$ thawed throughout the entire summer although there were monthly highs of $22{ }^{\circ} \mathrm{C}$ (Wagner 
and Yarmak, Jr. 2013). Ground temperatures for different soil depths and locations can be seen in Figure 18 - Figure 21.

Figure 18. Ground temperatures for several locations (ITTP1, ITTP7, ITTP10, ITTP11, and ITTP50) at various ground depths: surface (top, interface between ground surface, and insulation), $0.6 \mathrm{~m}, 1.2 \mathrm{~m}$, and $1.8 \mathrm{~m}$. The black dotted line indicates the $0^{\circ} \mathrm{C}$ freezing.

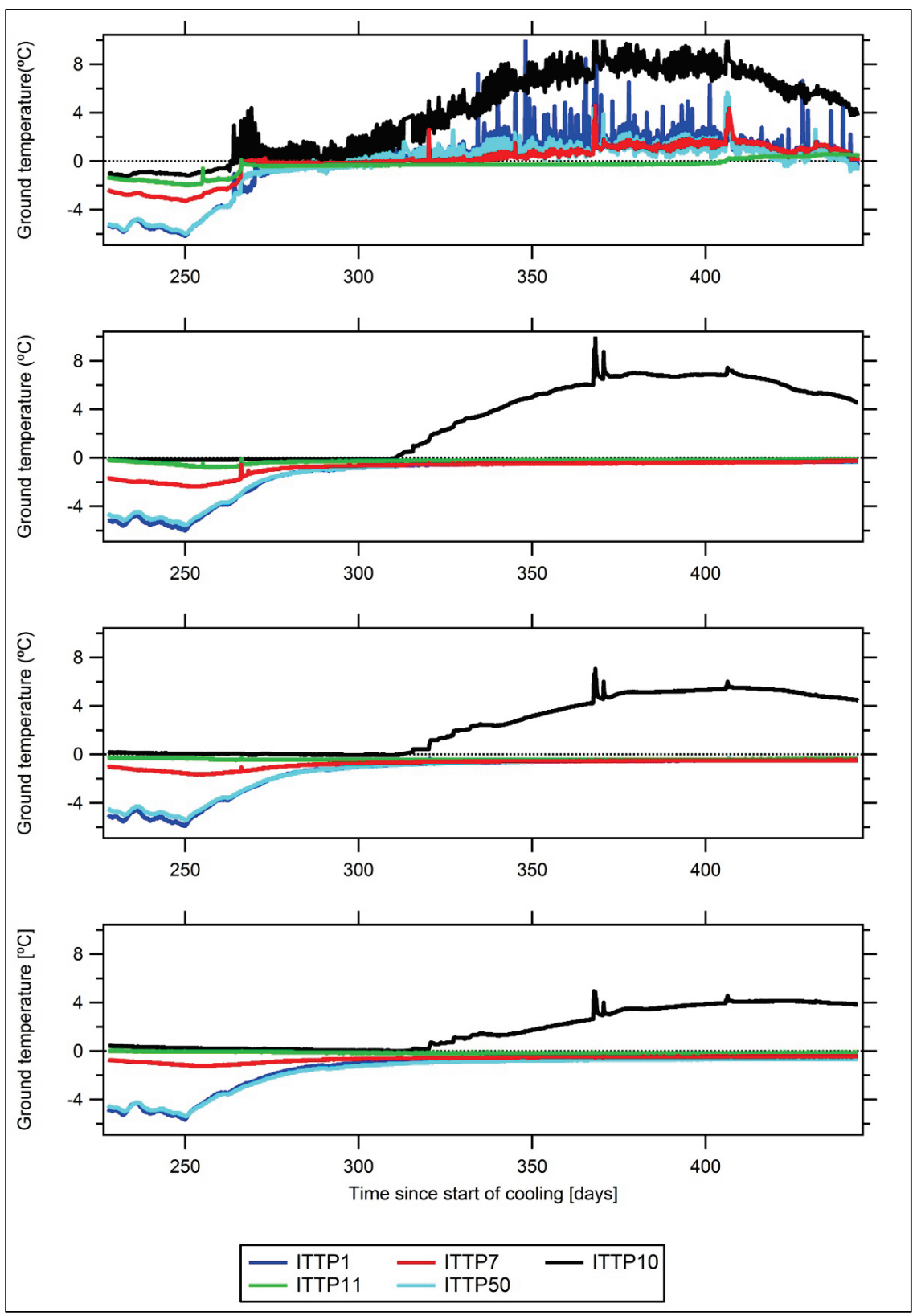


Figure 19. Ground temperatures for several locations (ITTP1, ITTP7, ITTP10, ITTP11, and ITTP50) at various ground depths: $2.4 \mathrm{~m}$ (top), $3.0 \mathrm{~m}, 4.6 \mathrm{~m}$, and $6.1 \mathrm{~m}$ (note that ITTP50 in second, third, and fourth graphs shows depths of $2.4 \mathrm{~m}, 4.0 \mathrm{~m}$, and $5.5 \mathrm{~m}$, respectively). The black dotted line indicates the $0{ }^{\circ} \mathrm{C}$ freezing.

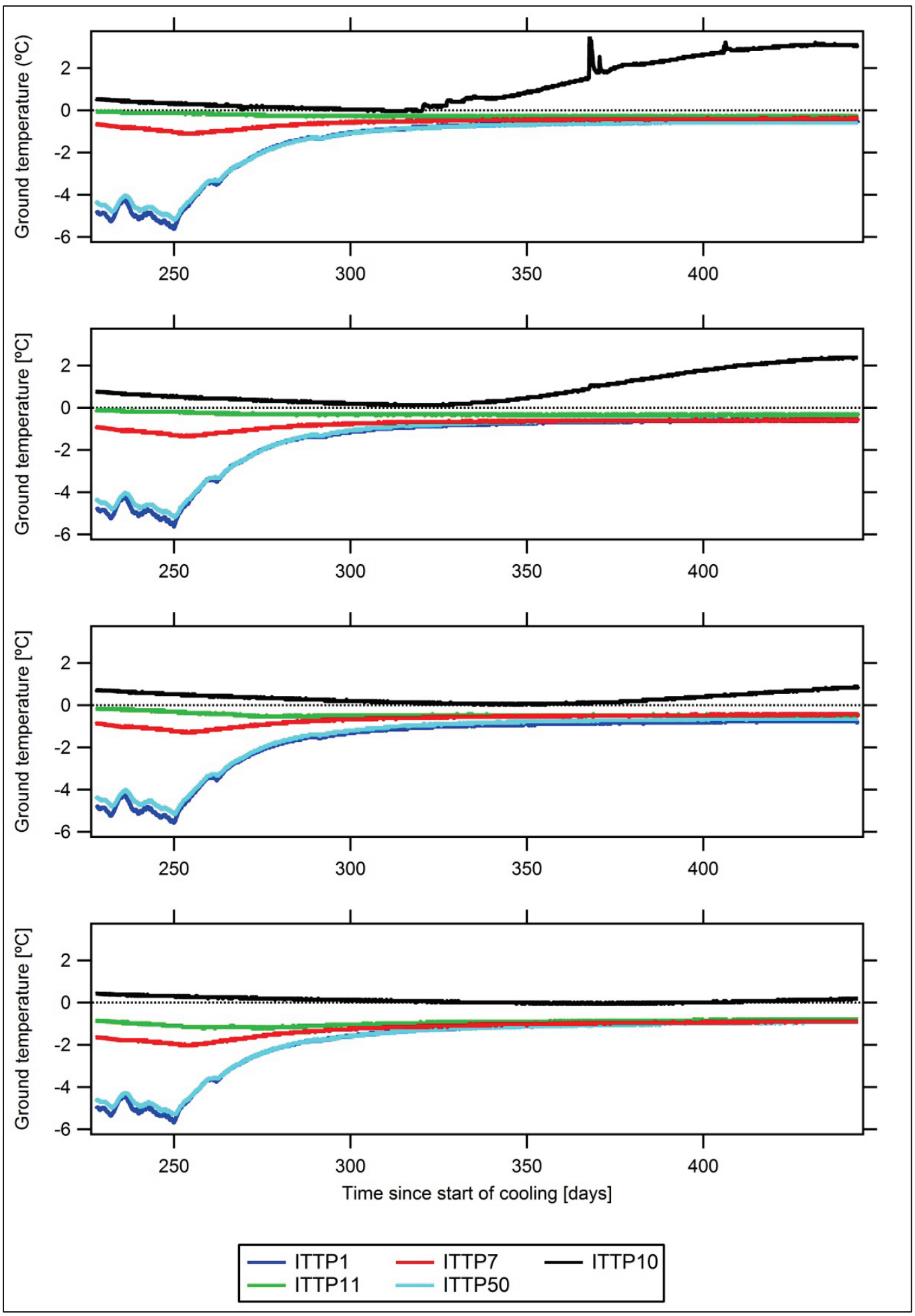


Figure 20. Ground temperatures for several locations (ITTP1, ITTP7, ITTP10, ITTP11, and ITTP50) at various ground depths: surface, $7.6 \mathrm{~m}, 9.1 \mathrm{~m}$, and $10.7 \mathrm{~m}$ (note that ITTP50 in all graphs shows depths of $7.0 \mathrm{~m}, 8.5 \mathrm{~m}$, and $10.0 \mathrm{~m}$, respectively). The black dotted line indicates the $0^{\circ} \mathrm{C}$ freezing.

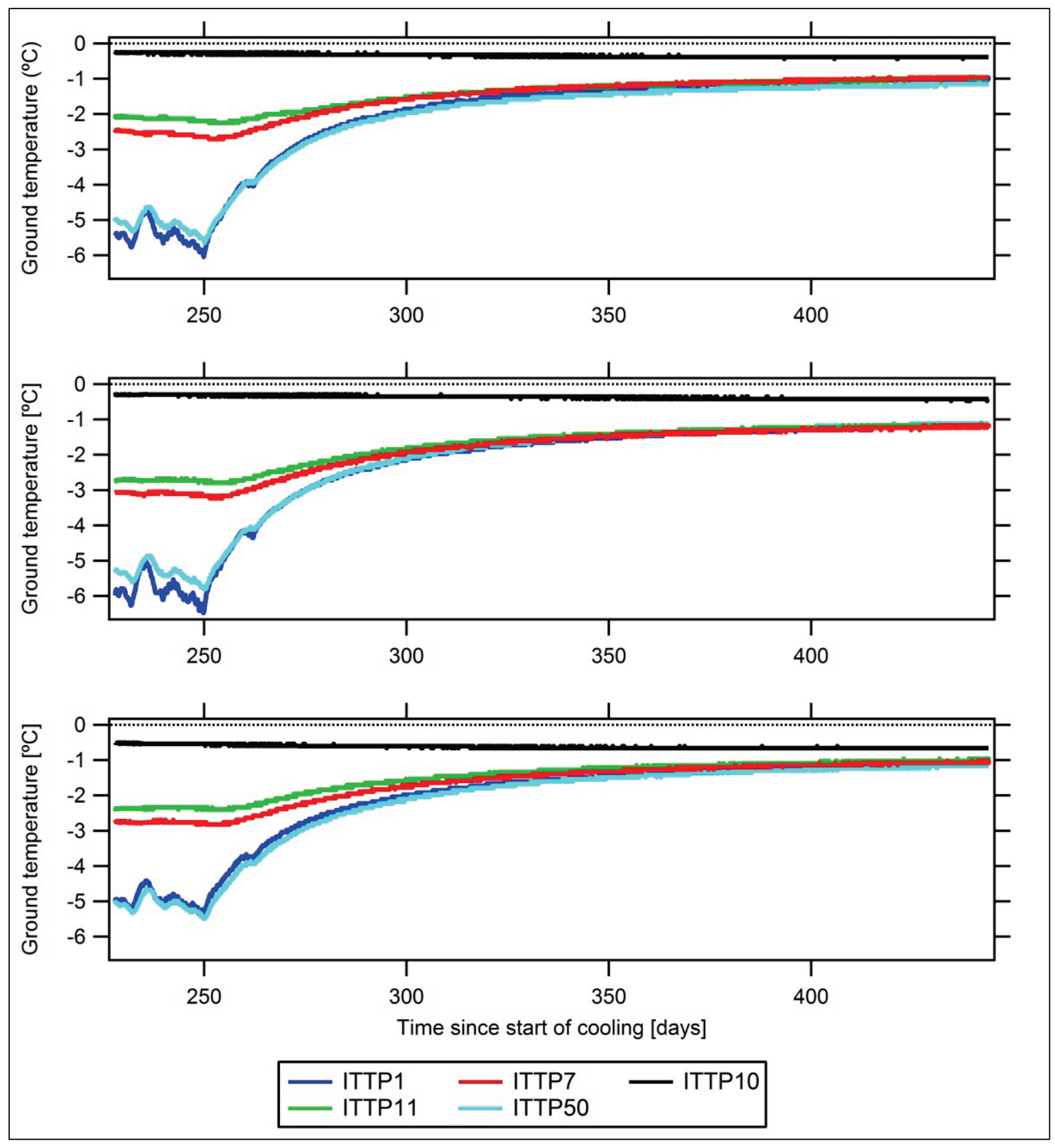


Figure 21. Ground temperatures for ITTP50 at depths of $11.6 \mathrm{~m}, 13.1 \mathrm{~m}$, and $14.6 \mathrm{~m}$. The black dotted line indicates the $0^{\circ} \mathrm{C}$ freezing.

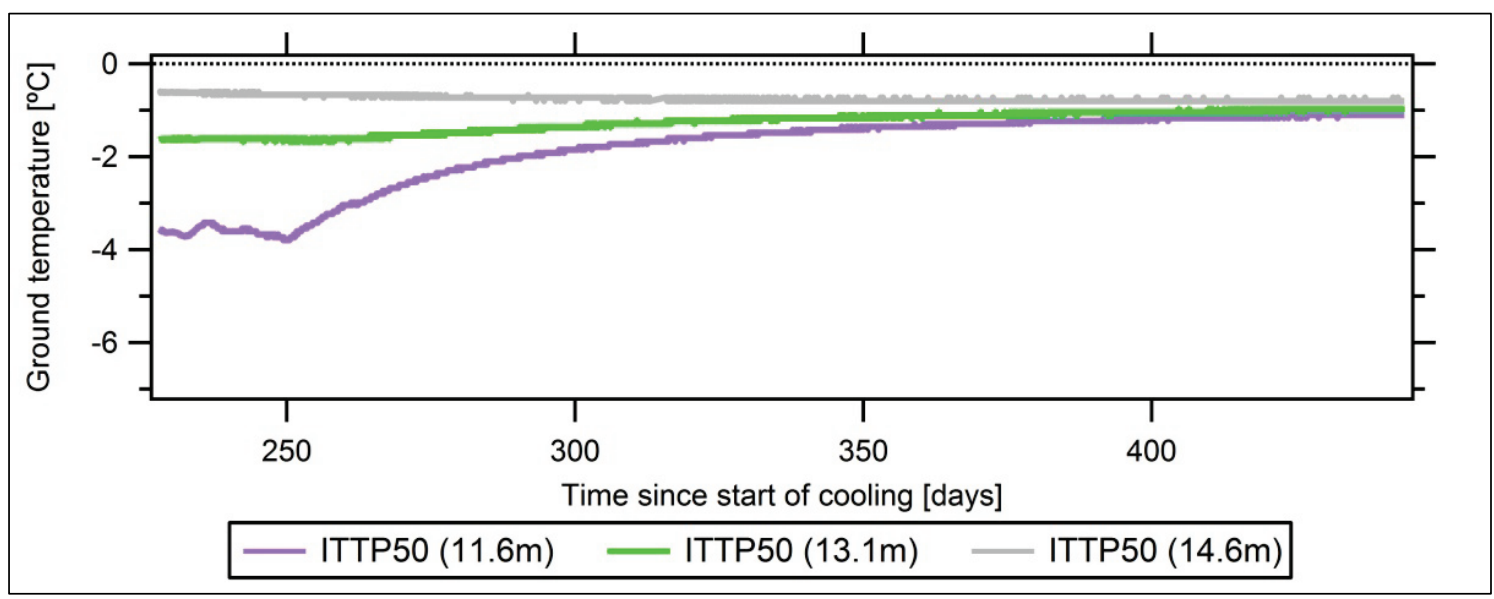




\section{Summary and Future Recommendations}

When groundwater becomes polluted, it can endanger public health or threaten the environment. Standard containment technologies include slurry walls, reactive barriers, sheet piling, grouting, or their combination. These are permanent structures that, once installed, are difficult and expensive to remove.

In this report, three approaches on how frozen barriers for containing a subsurface contaminated zone can be implemented are discussed. The first approach is to solidify the contaminants into a solid mass by freezing the entire contaminated zone. This approach can be used for smaller sites and where pipes cannot rupture from frost heave. The second approach is to contain the contaminants by creating a frozen barrier around a contaminated zone. Last, the third approach is to use a frozen barrier in conjunction with groundwater extraction wells as components of waste containment or pump and treat systems.

This study demonstrated successfully that frozen barriers can freeze quickly and will remain frozen. Conclusions of this demonstration are the following:

- Freezing to closure occurred after 42 days.

- The barrier was $1 \mathrm{~m}$ thick after approximately 48 days.

- The average electricity usage during freezedown was $92.16 \mathrm{kWh} / \mathrm{m}^{2}$ (2.19 $\mathrm{kWh} / \mathrm{m}^{2}$ day).

- The barrier was approximately $3.8 \mathrm{~m}$ wide at the end of the winter, and this width stayed frozen through the summer except for the top $0.5 \mathrm{~m}$.

- The barrier stayed frozen through the passive phase for more than a year.

- The frozen barrier is one tool in the engineer's toolbox to stop the spread of aqueous contaminants.

- Frozen barriers can be installed in a variety of site conditions where other barrier systems might not be suitable.

- Costs of frozen barriers are on par with other barrier systems.

The installation costs are very site specific. In the authors' case studies, it was shown that the installation cost of a frozen barrier would have been less expensive in two out of four cases when compared to a slurry wall 
installation. When comparing frozen barriers to slurry walls, a greater protection would be offered when frozen barriers are installed due to a frozen wall thickness approximately four times greater than the slurry wall thickness. It is recommended that estimates from contractors are obtained before a potential containment technique is omitted. 


\section{References}

Anchor Environmental, LLC. 2007. Groundwater/DNAPL Source Control Focused Feasibility Study. NW Natural "Gasco" Site. Portland, OR: Anchor Environmental, LLC.

Andersland, O. B., and B. Ladanyi. 1994. An Introduction to Frozen Ground Engineering. New York: Chapman \& Hall.

Andersland, O. B., D. C. Wiggert, and S. H. Davies. 1996a. "Frozen Soil Subsurface Barriers: Formation and Ice Erosion." Journal of Contaminant Hydrology 23: 133-147.

Andersland, O. B., D. C. Wiggert, and S. H. Davies. 1996b. "Hydraulic Conductivity of Frozen Granular Soils.” Journal of Environmental Engineering 122: 212-216.

Anderson, E. I., and E. Mesa. 2006. "The Effects of Vertical Barrier Walls on the Hydraulic Control of Contaminated Groundwater.” Advances in Water Resources 29: 89-98.

Braun, B., J. Shuster, and E. Burnham. 1979. "Ground Freezing for Support of Open Excavations.” Engineering Geology 13: 429-453.

Dash, J. G. 1991. “Ice Technology for Hazardous Waste Management.” Waste Management 11: 183-189.

Department of Defense (DoD). 1998. Evaluation of DoD Waste Site Groundwater PumpAnd-Treat Operations. Report No. 98-090. Washington DC: Office of the Inspector General.

Donaldson, F. 1912. Practical Shaft Sinking. 2nd edition. New York: McGraw-Hill.

Duyvesteyn, W. P. C. 2011. In Situ Ore Leaching Using Freeze Barriers. EMC Metals Corporation, United States Application 12/795,459.

Gerber, M. A., and M. J. Fayer. 1994. In Situ Remediation Integrated Program Evaluation and Assessment of Containment Technology. Washington, DC: U.S. Dept. of Energy, Office of Environmental Mangement, Office of Technology Development.

Hass, H., and P. Schafers. 2005. "Application of Ground Freezing for Underground Construction in Soft Ground.” In International Symposium on Geotechnical Aspects of Underground Construction in Soft Ground, 405-412. Edited by K. J. Bakker. London: Taylor \& Francis.

Hass, H., and P. Schäfers. 2006. "Application of Ground Freezing for Underground Construction in Soft Ground.” In Geotechnical Aspects of Underground Construction in Soft Ground. London: Taylor \& Francis.

Johnson, L. A., E. Yarmak, and E. L. Long. 2000. Cryogenic Barrier Demonstration Project. Final report. Oak Ridge, TN: U.S. Dept. of Energy. 
Jones, J. S., Jr. 1981. "State-of-the-Art Report - Engineering Practice in Artificial Ground Freezing.” Engineering Geology 18: 313-326.

Karol, R. H. 2003. Chemical Grouting and Soil Stabilization. 3rd edition. New York: M. Dekker.

Long, E. L., and E. Yarmak, Jr. 2000. "Engineering and Economic Variables of Long Duration Frozen Barriers.” International Symposium on Ground Freezing and Frost Action in Soils, Louvain-la-Neuve, Belgium.

Mann, M. J., K. K. Gupta, and B. C. Bower. 2009. "Interim Remedial Measure of a Radiological and Hazardous Waste Landfill Utilizing a Groundwater Diversion Barrier Wall and Exposed Geomembrane Cover System." Federation of New York Solid Waste Association Conference, Bolton Landing, NY.

McCauley, C. A., D. M. White, M. R. Lilly, and D. M. Nyman. 2002. "A Comparison of Hydraulic Conductivities, Permeabilities and Infiltration Rates in Frozen and Unfrozen Soils." Cold Regions Science and Technology 34: 117-125.

Mitchell, J. K., and W. A. N. van Court. 1997. "Barrier Design and Installation: Walls and Covers.” In Subsurface Restoration, xii. Edited by C. H. Ward, J. A. Cherry, and M. R. Scalf. Chelsea: Ann Arbor Press.

Newman, G., L. Newman, D. Chapman, and T. Harbicht. 2011. "Artificial Ground Freezing: An Environmental Best Practice at Cameco's Uranium Mining Operations in Northern Saskatchewan, Canada." In 11th International Mine Water Association Congress - Mine Water - Managing the Challenges. Edited by T. R. Rüde, A. Freund, and C. Wolkersdorfer. Aachen, Germany.

Nuclear Regulatory Commission (NRC). 2005. Contaminants in the Subsurface: Source Zone Assessment and Remediation. Washington, DC: National Academies Press.

Optiz, E., and B. Horne. 2001. "Kubaka Mine Tailings Design, Construction and Operation of a Frozen Core Dam: A Case Study.” In Proceedings, 2001 West Region Annual Conference, May 14-18, 2001, Sheraton Anchorage Hotel, Anchorage, Alaska. Association of State Dam Safety Officials.

Pearlman, L. 1999. Subsurface Containment and Monitoring Systems: Barriers and Beyond (Overview Report). National Network of Environmental Management Studies Fellow for U.S. Environmental Protection Agency.

Pimentel, E., G. Anagnostou, and A. Sres. 2010. "Large-Scale Physical Model for Simulation of Artificial Ground Freezing with Seepage Flow." In The 7 th International Conference on Physical Modelling in Geotechnics, 379-382. Zurich: CRC Press.

Ramage, J. 1988. "Lipari Landfill: Leachate Containment System - Geotechnical Considerations." In Second International Conferencd on Case Histories in Geotechnical Engineering, St. Louis, MO.

Richardson, P. 1979. Tough Alaska Conditions Prove New Pile Design's Versatility. Pages 20-28. Alaska Construction and Oil. 
Rumer, R. R., and M. E. Ryan. 1995. Barrier Containment Technologies for Environmental Remediation Applications. New York: Wiley.

Ryan, C. R. 1987. "Vertical Barriers in Soil for Pollution Containment." In Geotechnical Practice for Waste Disposal '87, ASCE, 182-204. American Society of Civil Engineers.

Rykaart, M., M. Millar, J. Kuryto, and L. Wade. 2015. "Evaluating the Performance of a Frozen Core Dam Founded on Ice Rich Saline Marine Silts and Clays." 68 $8^{\text {th }}$ Canadian Geotechnical Conference and $7^{\text {th }}$ Canadian Permafrost Conference, Quebec City, Canada.

Sanger, F. J. 1968. “Ground Freezing in Construction.” Journal of the Soil Mechanics and Foundations Division 94(1): 131-158.

Sanger, F. J., and F. H. Sayles. 1979. "Thermal and Rheological Computations for Artificially Frozen Ground Construction.” Engineering Geology 13: 311-337.

Sayles, F. N., and K. I. Iskandar. 1995. "Ground Freezing for Containment of Hazardous Waste.” International Containment Technology Workshop, Baltimore, MD, United States.

Shulski, M., and G. Wendler. 2007. The Climate of Alaska. Fairbanks, AK: University of Alaska Press.

Smoltczyk, U. 2003. Geotechnical Engineering Handbook. Vol. 2, Procedures. Berlin Chichester: Ernst \& Sohn.

Smoltczyk, U., H. Schad, E. Willand, W. Knickmeyer, and J. Klein. 1991. "Borehole-Jack Investigations in Frozen Ground of High Strength.” In 7th International Society for Rock Mechanics Congress, Aachen, Germany.

Smyth, D., R. Jowett, and M. Gamble. 1997. "Sealable Joint Steel Sheet Piling for Groundwater Control and Remediation: Case Histories.” International Containment Technology Conference, St. Petersburg, Florida.

Stoss, K., and J. Valk. 1979. "Uses and Limitations of Ground Freezing with Liquid Nitrogen.” Engineering Geology 13: 485-494.

Sullivan, D., S. Chase, and C. Dayton. 2009. "Employing Interim Water Management Barriers at Waste Disposal Area - 9255." Waste Management Conference, Phoenix, $A Z$.

Tatiya, R. R. 2005. "Shaft Sinking." Surface and Underground Excavations. United Kingdom: Taylor \& Francis.

U.S. Army Corps of Engineers (USACE). 1994. Technical Guidelines for Hazardous and Toxic Waste Treatment and Cleanup Activities. Washington, DC: U.S. Army Corps of Engineers.

U.S. Department of Energy (USDOE). 1995. Frozen Soil Barrier Technology. Innovative Irt. DOE/EM-0273. Washington, DC: U.S. Deparment of Energy, Office of Environmental Management, Office of Technology Development. 
. 1999. Frozen Soil Barrier. DOE/EM-0483. Washington DC: U.S. Department of Energy, Office of Environmental Management, Office of Science and Technology.

U.S. Energy Information Administration (USEIA). 2012.https://www.ElA.gov.

U.S. Environmental Protection Agency (USEPA). 1987. Construction Quality Control and Post-Construction Performance Verification for the Gilson Road Hazardous

Waste Site Cutoff Wall. Washington DC: U. S. Environmental Protection Agency.

1996. Pump-and-Treat Ground-Water Remediation: A Guide for Decision Makers and Practitioners. EPA/625/R-95/005. Washington DC: U.S.

Environmental Protection Agency, Office for Research and Development.

. 1998a. Abstracts of Remediation Case Studies, Volume 3. EPA 542-R-98-010.

Washington, DC: U.S. Environmental Protection Agency.

https://www.epa.gov/sites/production/files/2015-04/documents/abstractsvol3.pdf.

.1998b. Cost and Performance Report: Pump and Treat and Containment of Contaminated Groundwater at the Sylvester/Gilson Road Superfund Site Nashua, New Hampshire. Washington, DC: U.S. Environmental Protection Agency.

1998c. Evaluation of Subsurface Engineered Barriers at Waste Sites. EPA 542R-98-005. Washington, DC: U.S. Environmental Protection Agency, Office of Solid Waste and Emergency Response.

Wagner, A. M., and E. Yarmak, Jr. 2012. Demonstration of an Artificial Frozen Barrier: Installation Report. ERDC/CRREL TR-12-12. Vicksburg, MS: Cold Regions Research and Engineering Laboratory, U.S. Army Engineer Research and Development Center.

Wagner, A. M., and E. Yarmak, Jr. 2013. "The Performance of Artificial Frozen Barriers." In ISCORD 2013 Planning for Sustainable Cold Regions, 116-127. American Society of Civil Engineers. 


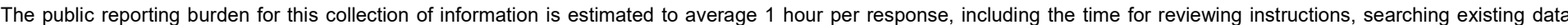

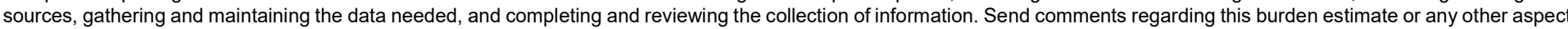

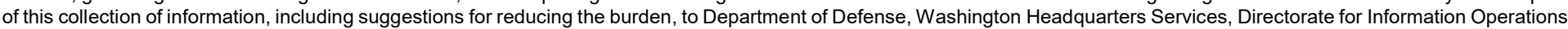

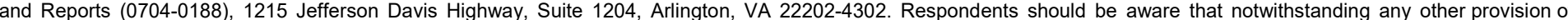
law, no person shall be subject to any penalty for failing to comply with a collection of information if it does not display a currently valid OMB control number.

PLEASE DO NOT RETURN YOUR FORM TO THE ABOVE ADDRESS.

\begin{tabular}{|l|l|l|l} 
1. REPORT DATE & 2. REPORT TYPE & 3. DATES COVERED (FrOm - TO)
\end{tabular}

September 2017

Final Report

4. TITLE AND SUBTITLE

Using Frozen Barriers for Containment of Contaminants

5a. CONTRACT NUMBER

5b. GRANT NUMBER

5c. PROGRAM ELEMENT NUMBER

5d. PROJECT NUMBER

FY12-55

5e. TASK NUMBER

5f. WORK UNIT NUMBER

8. PERFORMING ORGANIZATION REPORT NUMBER

ERDC/CRREL TR-17-14

10. SPONSOR/MONITOR'S ACRONYM(S) ACSIM

Office of the Assistant Chief of Staff for Installation Management

600 Army Pentagon

Washington, DC 20310

11. SPONSOR/MONITOR'S REPORT NUMBER(S)

12. DISTRIBUTION/AVAILABILITY STATEMENT

Approved for public release; distribution is unlimited.

\section{SUPPLEMENTARY NOTES}

\section{ABSTRACT}

In the summer of 2011, a full-scale test of a frozen soil barrier was deployed at the Cold Regions Research and Engineering Laboratory site in Fairbanks, AK. Hybrid thermosyphons, a more efficient cooling technology than conventional ground freezing, were used to create the frozen soil. The hybrid units were actively cooled by a 4.5 kilowatt refrigeration condensing unit for 62 days. A vertical frozen barrier of 9 meters $(\mathrm{m})$ extending from a depth of $7 \mathrm{~m}$ below the surface to the ground surface was completed in 42 days, and the barrier was $1 \mathrm{~m}$ thick in 48 days. This frozen barrier installation has successfully shown that this technology can freeze the ground quickly. At the end of winter 2012, the barrier was approximately $3.8 \mathrm{~m}$ thick. This barrier thickness was maintained throughout the summer of 2012 . The results showed only the top $0.5 \mathrm{~m}$ thawed even though the system was inactive for approximately a year. A cost analysis was performed to compare the cost of frozen barriers and slurry walls. It was concluded that construction and operating and maintenance costs of frozen barriers are on par with other barrier systems.

\section{SUBJECT TERMS}

Groundwater-Pollution, Groundwater-Purification, Soil freezing, Thermosyphons

\section{SECURITY CLASSIFICATION OF:}

\begin{tabular}{|l|l|l|l|} 
a. REPORT & b. ABSTRACT & c. THIS PAGE & ABSTRACT \\
Unclassified & Unclassified & Unclassified & SAR \\
\end{tabular}

18. NUMBER OF 19a. NAME OF RESPONSIBLE PERSON PAGES $\quad$ Anna M. Wagner

54 19b. TELEPHONE NUMBER (Include area code) 907-361-5459 
7. PERFORMING ORGANIZATION NAME(S) AND ADDRESS(ES) (concluded

Cold Regions Research and Engineering Laboratory

U.S. Army Engineer Research and Development Center

72 Lyme Road

Hanover, NH 03755

Arctic Foundations Inc.

5621 Arctic Boulevard

Anchorage, AK 99518-1667 